\title{
COVID-19: Invades Erythrocytes through Plasmodium Falciparum Antigen and Complement-Like System
}

\author{
Wenzhong Liu ${ }^{1,2, *}$, Hualan $\mathrm{Li}^{2}$ \\ 1 School of Computer Science and Engineering, Sichuan University of Science \& Engineering, \\ Zigong, 643002, China; \\ 2 School of Life Science and Food Engineering, Yibin University, Yibin, 644000, China; \\ ${ }^{*}$ Correspondence.Wenzhong Liu, liuwz@suse.edu.cn.
}

\begin{abstract}
Malaria symptoms are very similar to those of COVID-19, and infections can be symptomatic or asymptomatic. Common immunodominant epitopes are shared by the SARS-CoV-2 proteins and the Plasmodium falciparum antigen. Through bioinformatics methods such as domain search, this study discovered that the S, ORF3a proteins contained Plasmodium antigens rich in tryptophan and threonine. ORF3a, ORF8, S, and $\mathrm{N}$ and others also had more extended autotransporter domains. The Plasmodium antigen of S protein contained a C1q domain capable of binding to the complement receptor 1 on the red blood cell membrane. ORF3a contained the Plasmodium antigen EBA-175 domain, which was capable of binding to glycophorin A on the red blood cell membrane. S and ORF3a were bound to band 4.1 to anchor on the erythrocyte membrane skeleton, respectively. The Membrane attack complex component of the $\mathrm{S}$ protein formed fusion pores on the red blood cell membrane. Then it injected viral genetic material into the mature red blood cell. ORF3a used a thiol-activated cytolysin domain to create hemolytic pores in the red blood cell membrane. The coagulation factor calcium ions were involved in the red blood cell invasion process. The invasion would have no discernible hemolysis or hypoxia reactions. According to the Plasmodium antigen type for SARS-COV-2, the blood cells of people with blood types A and Knops were susceptible to attack by SARS-COV-2 virus proteins.
\end{abstract}

Keywords:Malaria; Complement Receptor 1; C1q; EBA-175; Coagulation; Hemolysis; Oxygen dissociation curve

\section{Background}

Malaria has symptoms that are strikingly similar to COVID-19. Plasmodium malaria symptoms are non-specific and include chills, vomiting, malaise, headache, fever, and myalgia. It is extremely difficult to reliably distinguish from other febrile diseases(1). Plasmodium vivax infection has been linked to severe anemia, respiratory distresss(2), malnutrition(3), and coma(4). In vivax malaria, high fever and chills are more common than in falciparum malaria. COVID-19's early symptoms, such as myalgia, fever, and fatigue, may be mistaken for malaria symptoms(5). With the same Plasmodium falciparum, infection can range from subclinical to fatal. Malaria, like COVID-19, has both symptomatic and asymptomatic forms(6). Plasmodium and SARS-CoV-2 have a similar incubation period(5). SARS-CoV-2 has an incubation period of 11.5 days, while Plasmodium has an incubation period of 7 to 30 days. A few clinical cases of malaria and COVID-19 co-infection have been reported(7,8). Distinguishing the two diseases has become 
extremely difficult in impoverished areas with a high prevalence of malaria.

Plasmodium infects red blood cells in the following manner(9): To begin, heparin activates the interaction and deforms the red blood cells slightly. The growth factor receptor (GFR) plays a role in the entry and replication of viruses. Numerous viruses attach to and enter human cells via GFR, including heparan sulfate proteoglycan (HSPG) (10). The second step is that the malaria parasite's actin-myosin causes the malaria proteins (EBA and PfRh) to bend red blood cells strongly. The malaria parasite protein then binds to the red blood cell receptor, forming a fusion pore. Along the pipeline, small molecules and invading components enter the red blood cell. The malaria protein is bound to the erythrocyte membrane skeletal protein (spectrum, actin, ankyrin, protein 4.1). The EBAs and Rhs are two major parasite protein families. Three EBAs are receptors for members of the glycophorin family(11). Complement receptor 1 (CD35, for example) has been identified as a PfRh4 receptor(11). Complement receptor type 1 (CR1, CD35) is a C1q receptor(12). PfRh5 is homologous to the antigen basigin of the Ok blood group (BSG, also known as CD147(13), EMMPRIN, and M6) (14). The final step is the AMA1-RON2 interaction (15), which mediates tight junction formation and anchors for the internalization point. The motor, MTRAP (homolog of thrombin-sensitive protein), and other kinetic system proteins complete the process of plasmodium's rapid slide into red blood cells. If the COVID-19 virus also employs thrombin-sensitized protein-mediated entry into red blood cells, it may account for some of the systemic coagulation observed in severe patients.

Genetic factors such as ABO blood type and ACE2 receptor can also account for the unnatural link between malaria and COVID-19(16). Humans have been infected and co-evolved with malaria(17). Numerous human polymorphisms are associated with this process of natural selection(18). Genetic variants for malaria may also contribute to the incidence and severity of SARS-CoV-2 infections (for example, ACE2 receptors) (16). There are four glycoproteins(19) in humans: A, B, C, and D. These glycoproteins contain sialylated O-glycans and/or N-glycans. They interact with the Plasmodium falciparum ligands EBA-175, EBL-1, EBA-140, and EBA-140, respectively(19). Gerbich antigens are expressed on glycophorin C (GPC) and glycophorin D (GPD) (20). Generally, Gerbich antibodies do not result in severe hemolytic transfusion reactions (HTR) (20). Autoantibodies directed against Ge2 or Ge3 can result in autoimmune hemolytic anemia (AIHA) (20). During the initial adhesion phase of malaria parasites invading red blood cells, the merozoite surface protein 1-glycophore protein A-band 3 (MSP1-GPA-band 3) complex exerts its influence (21). Plasmodium falciparum cannot infect red blood cells deficient in glycoproteins A and B (M k phenotype) (22). COVID-19 infection and mortality rates are skewed toward patients with blood type A and away from those with blood type O (23). Patients with type $\mathrm{O}$ have natural IgM antibodies against both anti-A and anti-B. These antibodies may contribute to the host's viral load reduction and result in milder symptoms(24). SARS-CoV-1 exhibits similar characteristics(25). Thus, malaria and COVID-19 blood type infection rules are identical. Similar hemolytic reactions will occur if SARS-COV-2 has the same structure to invade red blood cells.

The proteins of SARS-CoV-2 and the antigen of Plasmodium falciparum share immunodominant epitopes(26). Generally, Plasmodium vivax infects host red blood cells via the Duffy antigen(27). Antibodies against band 3 and spectrin accumulate during Plasmodium vivax infection and are associated with anemia(28). The disease triggers the autoimmune response. Hemoglobin levels are inversely related to those of anti-band 3 or anti-spectrin antibodies. Anemic patients have higher IgG levels for band 3 and spectrin than non-anemic patients. Plasmodium 
vivax can also infect host cells via other mechanisms in Duffy-negative populations(29). Tryptophan-threonine-rich antigen (TryThrA) is a Plasmodium falciparum homologue of the erythrocyte membrane pypAg-1 antigen produced by Plasmodium yoelii. TryThrA is a tryptophan-rich antigen expressed by various Plasmodium species' merozoites. TR-Ags from Plasmodium can be combined with normal human red blood cells. The process can be slowed down by the serum of a malaria patient(30). Through the tryptophan-rich threonine antigen (PfTryThrA), Plasmodium falciparum infects host red blood cells(31). PvTRAg38 (P. vivax tryptophan-rich antigen) binds to red blood cell receptors sensitive to chymotrypsin(32). PvTRAg38 promotes Parasite growth by binding to the two red blood cell receptors Basigin and Band 3, via their P2 and $\mathrm{P} 4$ regions, respectively(33). Band 3 protein is also a parasite protein's chymotrypsin-sensitive red blood cell receptor(34). In COVID-19 patients, studies have revealed that the function of red blood cell membrane proteins such as band 3 is impaired(35). It demonstrates that the SARS-CoV-2 virus protein interacts with the structural proteins of red blood cells via TryThrA and other Plasmodium falciparum antigens.

Some viral proteins also contain tryptophan-rich motifs. The tryptophan-rich region at the immunodeficiency virus gp41(36) proximal membrane end is involved in hydrophobic subunit interactions(37). It is required for the fusion of ENV proteins and viral infectivity(38). The carboxyl-terminal tryptophan-rich motif of the hepatitis B virus small envelope protein is critical for hepatitis D virus particle assembly(39). When influenza virus RNA's 5' end sequence is bound to the polymerase, the tryptophan-rich cap-binding sequence on the enzyme's PB2 subunit is activated(40). Shared antigens cause Cross-reactions between viral and malaria infections. The association between malaria and the risk of death in patients with the Ebola virus suggests that the P. falciparum parasite and the Ebola virus have an intra-host interaction(41). Semi-monkeys were not protected from malaria by recombinant vaccinia virus expressing Plasmodium falciparum antigens(42). Only the monoclonal antibody (MAb) to TNF-, on the other hand, inhibited malaria antigen-induced HIV-1 replication. By contrast, the monoclonal antibody does not affect IL-6 production(43). Malaria antigens promote HIV-1 replication by increasing viral mRNA expression and activating viral transcription directed by long-terminal repeats(43). TNF-, IFN-, MIF, MCP-1, and IL-10 have been detected in patients with falciparum and vivax malaria(44). Plasmodium-infected patients exhibit positive immunoglobulin IgM and IgG responses(44). Tumor necrosis factor (TNF-) and interleukin 6 levels were increased in response to malaria antigen stimulation (IL-6). TNF- and IL-6 are also the primary cytokines in COVID-19 patients. Besides, patients with acute malaria infection exhibit a high degree of cross-reactivity with the SARS-CoV-2 spike protein subunit 1 (S1) (45). The receptor-binding domain (RBD) and the $\mathrm{N}$-terminal domain (NTD) are the two central regions targeted by neutralizing antibodies in Spike S1(45). Acute malaria infections can induce cross-reactions with the S1 Spike protein via antibodies binding to the terminal sialic acid of complex glycans(45). As a result, the SARS-COV-2 virus must infect host cells via Plasmodium falciparum antigens such as TryThrA and induce the production of cytokines.

Invading a host's red blood cells via the complement-complement receptor pathway has garnered considerable attention as a viral infection route. According to clinical and experimental evidence, complement is implicated in both intrahepatic and extrahepatic manifestations of chronic hepatitis $\mathrm{C}$ virus (HCV) infection(46). Direct Binding of the Complement Component C1q to Coinfected Cells with Human Immunodeficiency Virus (HIV) and Human $\mathrm{T}$ 
Lymphotrophic Virus-I (HTLV-I) (47). In vitro and in vivo, C1q inhibits antibody-dependent enhancement (ADE) of flavivirus infection in a subclass-specific manner(48). However, the Ebola virus (EBOV) uses the complement component $\mathrm{Clq}$ to enhance infection via antibody(49). The Ebola virus (EBOV)-antibody-C1q complex is cross-linked with the C1q receptor on the cell surface, increasing the virus's ability to enter the cell(49). The spectrum of human C1q is identical to that of the ZIKV E protein(50). It is, however, distinct from the E protein produced by the West Nile virus(50). Dengue virus infection and transcription of inflammatory molecules in THP-1 cells are decreased when C1q binds to the dengue virus(51). Symptoms of an activated complement system include paroxysmal nocturnal hemoglobinuria, atypical hemolytic uremic syndrome, and catastrophic antiphospholipid syndrome in patients with COVID-19(52). The alternative approach plays a critical role. The classical complement pathway is activated before the onset of pneumonia during virus clearance(24). Complement activation contributes to systemic diseases associated with lung pathology and SARS-CoV infection(53). In comparison to mice lacking C4 or factor B, mice lacking $\mathrm{C} 3$ are more resistant to infection with SARS-CoV MA15(53). This demonstrates that diseases caused by SARS-CoV involve multiple complement cascade components(53). The complement replacement pathway associated with severe COVID-19 is activated and amplified in patients with this more severe disease. It has been associated with markers of endothelial injury and hypercoagulability(54). The most severe COVID-19 patients experience cytokine storms, endothelial inflammation (endothelitis), and thrombosis due to the complement system being overactivated(55). However, patients treated with complement inhibitors recovered without experiencing any adverse effects (56).

Multiple complement pathways are activated during coronavirus infection(57). The complement system is activated in three distinct ways: classical antibody-dependent activation, lectin-dependent activation, and alternative (AP) activation(58). Regardless of the initial activation steps, the system's primary objective will be to lyse $\mathrm{C} 3$. Then $\mathrm{C} 5$ is lysed to produce anaphylatoxins ( $\mathrm{C} 3 \mathrm{a}$ and $\mathrm{C} 5 \mathrm{a}$ ). They have the potential to induce vasodilation, chemotaxis, and thrombosis(55). System activation promotes the formation of the membrane attack complex (MAC) (i.e., C5b-9) (58). Coronaviruses cause the complement system to malfunction. The interaction of the coronavirus's $\mathrm{N}$ protein with a membrane-associated serine protease(59) initiates the lectin pathway(60). By inhibiting factor D or C5, SARS-CoV-2 spike protein (subunits S1 and S2) activates $\mathrm{AP}(61)$ and ameliorates immunopathology. Immune complexes and C-reactive protein can also activate the classical pathway(60). However, some viruses employ distinct strategies for inhibiting and exploiting complement activation(62). By expressing complement-like regulatory proteins, poxviruses inhibit complement activation(63). By hijacking complement regulators, flaviviruses impair complement antiviral activity(62). HIV-1 recruits complement regulators from the host into its virions(62). The virus can impair the antiviral response by severing the $\mathrm{C} 3$ molecule attached to the virus's surface(64). As a result, SARS-CoV-2 possessed complement-like proteins (such as C1q) that contributed to the activity of invading red blood cells in a complement-complement receptor-dependent manner. When these complement-like $\mathrm{C} 1 \mathrm{q}$ proteins were activated, they inadvertently activated $\mathrm{C} 3$, activating the complement system.

A membrane attack complex domain is present in the Plasmodium sporozoite protein(65). Before hepatocyte infection, it destroys the sinusoidal cell layer. The molecule's pore-forming activity is required for sporozoites to pass through the host's plasma membrane(65). Similar to the 
complement membrane attack complex, the SARS-CoV-2 protein can also construct cell membrane pores. Near the transmembrane region of the SARS-CoV-2 S protein, the HAP2/GCS1 and Izumo-Ig domains promote the formation of membrane fusion pores(66). This overlapping region contains $\mathrm{Ca} 2+-\mathrm{ATPase}$, actin-myosin motor, and phospholipid flippase structures. These sequences are involved in $\mathrm{Ca} 2+$-dependent hemolysis and coagulation. The membrane attack complex (MAC, C5b-9) can perforate the membrane of a target cell(55). S also contains a membrane attack complex domain, which can be involved in forming fusion pores invading red blood cells. Hemolysin is a type of perforin that specifically targets infected cells. Hemolysin is more resistant to heat(67). The fusion protein of the small ruminant plague virus is a hemolysin(68). Newcastle disease virus hemolysin(69) is sufficient to lyse red blood cells(70). Measles virus hemolysin shares many properties with myxovirus hemolysin(67). It predisposes red blood cells to hemagglutination and hemolysis. Equine encephalomyelitis viruses are hemolytic over a wide temperature range(71). Specific $\mathrm{pH}$ changes reduced their hemolytic activity. However, trypsin treatment significantly increased the viruses' hemagglutinating activity (71). Under conditions of heating, formaldehyde, and ultraviolet radiation, the mumps virus retains almost all of its hemolytic activity and infectivity(72). SARS-CoV-2 nsp3 is a component of the organelle's double-membrane pore complex(73). On the proteoliposome bilayer membrane, the SARS-CoV-2 ORF3a polymer forms a $\mathrm{Ca}^{2+}$ channel(74). SARS-CoV-2 ORF8 is a very short membrane peptide with a single channel span. It forms cation-selective channels when assembled in lipid bilayers(75). ORF3a and ORF8 have pore-forming properties. It suggested that they were SARS-CoV-2 hemolysin proteins. ORF3a is capable of forming not only dimers but also tetramers(74). Then it can form larger hemolytic pores in the cell membrane. It may be a critical entry point for viral proteins into the host cell.

Cytolysin binds to the target cell's surface receptor (glycoprotein, carbohydrate, or lipid) (76). The subdomains of the cell membrane that contain cholesterol are frequently referred to as lipid "rafts"(77). The transport of macromolecules into malaria-infected cells is facilitated by lipid rafts (78). Experiments with cholesterol-depleted red blood cells demonstrated that red blood cells become resistant to parasite invasion after depletion. It implies a role for lipid rafts in parasite invasion. Lecithin and cholesterol are critical components of the cell membrane of red blood cells, where they react with viral hemolysin(79). Cholesterol-dependent cytolysin (CDC) is a MACPF superfamily member. Cytolysin can create holes (25-30 nanometers in diameter) in the cell membrane where cholesterol is present $(80)$. However, cholesterol is not required for this cytolysin to adhere to target cells(80). The cytolysin is oxygen-sensitive(81), and its activity decreases in a high-oxygen environment(82). Cholesterol promotes the fusion and infection of the alphaviruses Semliki Forest virus (SFV) and Sindbis virus significantly(83). SFV's E1 fusion protein binds to cholesterol(83). However, numerous dengue virus (DV) fusions and infections with yellow fever virus 17D are unrelated to cholesterol(83). The DV fusion protein exhibits no detectable cholesterol-binding activity(83). Cholesterol-dependent cytolysin may activate their hemolysin activity in hypoxic COVID-19 patients.

Severe COVID-19 ill patients with acquired methemoglobinemia lead to refractory hypoxia and require red blood cell transfusion for treatment(84). The prevalence of beta thalassemia heterozygotes is related to immunity to COVID-19(85). Patients with sickle cell disease and laboratory-confirmed COVID-19 usually have a mild or insignificant course. They face lower chances of intubation, ICU admission, and death, but a slightly longer hospital stay(86). In some 
epidemic areas, patients with severe COVID-19 patients have lower hemoglobin levels than those with mild illnesses, and lower hemoglobin levels can lead to anemia and complications(87).HP*2 alleles provide protection for certain people through its anti-inflammatory response from the severe impact of COVID-19 and other infectious diseases(88). The main function of haptoglobin is to combine with free hemoglobin to form a stable complex, and then it is processed by the mononuclear-macrophage system. There is a correlation between decreased serum hemoglobin and increased levels of ferritin and $\operatorname{LDH}(89)$. Since excessive hemoglobin phenotype, it is not entirely clear whether patients with thalassemia are particularly susceptible to SARS-COV-2, or whether they have a higher risk of complications from COVID-19 than the normal population(90).

COVID-19 patients who become critically ill as acquired methemoglobinemia develop refractory hypoxia and require red blood cell transfusions for treatment $(84)$. The prevalence of beta-thalassemia heterozygotes is associated with COVID-19 immunity(85). Patients with sickle cell disease and laboratory-confirmed COVID-19 typically have a mild or insignificant course. They have a lower risk of intubation, ICU admission, or death but require a slightly more extended hospital stay(86). Severe COVID-19 Patients have lower hemoglobin levels than those with mild illnesses in some epidemic areas. And low hemoglobin levels can result in anemia and complications(87). HP*2 alleles protect specific individuals from the severe effects of COVID-19 and other infectious diseases through their anti-inflammatory response(88). The primary function of haptoglobin is to form a stable complex with free hemoglobin, which is then processed by the mononuclear-macrophage system. There is a correlation between low serum hemoglobin levels and increased ferritin and LDH levels (89). Due to the excessive hemoglobin phenotype, it is unknown whether patients with thalassemia are more susceptible to SARS-COV-2 or have a higher risk of COVID-19 complications than the general population(90).

The serum of COVID-19 patients contained proteins such as ORF1ab, ORF3a, ORF8, S, and N. Antibody detection methods for these proteins are also used to confirm the infection with SARS-COV-2. It demonstrates that viral proteins can also be secreted into the serum by infected cells. ORF3a, and S protein must be secreted into serum to attack red blood cells. The V-type pathway was initially described as the IgA1 protease. It ensures that the proteins secreted through the outer membrane are completely contained within the secreted protein $(91,92)$. An autotransporter is a protein that is secreted in this manner(93) (Autotransporter). Some proteins autocatalyze cleavage after the Autotransporter domain induces itself export, while others dose not (94). Some eukaryotic viruses use the asparagine-aspartate self-cleavage mechanism during capsid maturation(95). The SARS-COV-2 virus protein may also use an autocrine mechanism similar to this.

We studied the SARS-CoV-2 virus proteins using the domain search method. This current study discovered that ORF3a, $\mathrm{S}$, and $\mathrm{N}$ viruses and others had more extended Autotransporter domains. The SARS-CoV-2 virus proteins $\mathrm{S}$ and ORF3a invaded immature red blood cells like Plasmodium falciparum using Plasmodium falciparum-like antigen or complement C1q. Through perforated holes in the oxygen-sensitive hemolysin, the SARS-CoV-2 virus protein ORF3a, S entered the red blood cells. Both invasion conditions resulted in red blood cell dysfunction.

\section{Methods}

\subsection{Data collection}


1. The SARS-COV-2 protein sequences. The NCBI database was used to obtain the SARS-COV-2 protein sequences. All included S, E, N, M, ORF3a, ORF8, ORF7a, ORF7b, ORF6, ORF10, and ORF1ab.

2. Sequences that are related. The corresponding sequences were obtained from the UniProt data set (Table 1).

\subsection{A localized MEME tool to identify conserved domains.}

The following are the steps involved in the analysis:

1. Downloaded MEME from the official website and installed it in a virtual machine running Ubuntu. VM 15 was the virtual machine.

2. Downloaded the SARS-COV-2 protein sequence from the National Center for Biotechnology Information's official website.

3. Obtained the fasta format sequences of the related protein from the official Uniprot website.

4. Generated fasta format files by MEME analysis for each sequence in all related proteins and each SARS-COV-2 protein sequence.

5. To create multiple batches of the files generated in Step 4, a batch size of 50000 was used. It was limited by the virtual ubuntu system's limited storage space.

6. Using MEME tools in batches, searched for conserved domains $(E-v a l u e<=0.05)$ in SARS-COV-2 and related proteins in Ubuntu.

7. Collected the conserved domains' result files. Located the domain name associated with the motif in the UniProt database.

8. Analyzed the activity of each SARS-COV-2 protein's domains.

\section{RESULTS}

\subsection{Antigenic domains of Plasmodium falciparum and EBA-175}

We obtained the sequences encoding the antigen from the UniProt database. Then, using local MEME tools, we compared these sequences to viral proteins in order to identify conserved domains. We merged the search results by protein and domain because there were too many motif fragments. The results are summarized in Tables 2 and 3.

As shown in Table 2, the SARS-COV-2 virus structural proteins (S, E, M, N) and non-structural proteins (ORF3a, ORF6, ORF7a, ORF7b, ORF8, ORF10, and ORF1ab) contain the TryThrA_C domain of the malaria parasite antigen. The TryThrA_C domain (PF12319) is at the C-terminus of the Plasmodium malaria surface antigen. Plasmodium antigens with a high tryptophan-threonine content (TryThrA) are typically between 254 and 536 amino acids in length. S, M, N, ORF3a, ORF7a, and ORF8 are longer than ORF6, ORF7b, ORF10, and E.

As shown in Table 3, the SARS-COV-2 virus structural proteins (E, $\mathrm{M}$, and $\mathrm{N}$ ) and non-structural proteins (ORF3a, ORF6, ORF7a, ORF7b, ORF8, ORF10, and ORF1ab) contain the Plasmodium antigen's EBA-175 VI domain (PF11556). The EBA-175 VI domain encodes the red blood cell binding antigen 175, and this family represents region VI. EBA-175 interacts with glycophorin GPA, assisting in forming tight junctions, a necessary step for invasion. VI is a cysteine-rich domain that is required for EBA-175 trafficking. EBA-175 is an alpha helix-containing homodimer. N, ORF3a, and ORF8 all can form dimers. N's EBA-175 VI domain, 
on the other hand, is concise and does not contain cysteine. As a result, the EBA-175 VI domains of N, E, M, ORF6, ORF7a, ORF7b, and ORF10 are incapable of exhibiting complete GPA binding activity. ORF3a and ORF8 have EBA-175 VI domains that overlap with TryThrA_C domains, respectively. Thus, ORF3a and ORF8 may bind to the red blood cell membrane's glycophorin GPA via the Plasmodium antigen (EBA-175 VI) rich in the amino acid threonine.

Unexpectedly, the $\mathrm{S}$ protein lacks the EBA-175 VI domain. Other invasive binding mechanisms may be used by $\mathrm{S}$ protein.

\subsection{Domains of the complement C1q and membrane attack complex}

C1q (IPR001073) contains a small spherical N-terminal domain, a collagen-rich central Gly/Pro region, and a conserved C-terminal region(96). The C-terminal globular domain of the C1q subfraction and collagen is required for the triple helix to fold correctly and for protein-protein recognition events to occur(97). The domain is found in multimeric proteins and EMILIN proteins. It is required for the proper assembly of proteins(98). The $\mathrm{Clq}$ domain's globular head is a trimer(99). C1q is also a complement receptor 1 binding protein found on the surface of red blood cells.

We downloaded complement-related sequences from the UniProt database to determine which viral proteins contain the $\mathrm{Clq}$ domain. Then, using native MEME tools, compare these sequences to viral proteins to identify conserved domains. Due to the more number of motifs, we combined the motif search results by protein and domain. The C1q domain motifs of the SARS-COV-2 virus proteins are listed in Table 4. As demonstrated in Table 4, structural proteins (S, E, M, and N) and non-structural proteins (ORF3a, ORF6, ORF7a, ORF7b, ORF8, ORF10, nsp2, nsp4, 3c-like) contain $\mathrm{C} 1 \mathrm{q}$ domain motifs. nsp2, nsp4, and 3c-like all have concise $\mathrm{C} 1 \mathrm{q}$ motifs. Among the four S C1q A-D motifs, the relatively conservative $\mathrm{C}$-terminal regions of $\mathrm{S} \mathrm{C1q} \mathrm{C}$ and $\mathrm{D}$ are required for membrane fusion. $\mathrm{S} \mathrm{C1q} \mathrm{C}$ is located in the EF-hand region and has a spherical area, activating $\mathrm{S} 2$ and initiating membrane fusion. S C1q A and B are located at the $\mathrm{N}$ terminal. S C1q A is in the S1 protein's globular head region. S C1q is homologous to the TryThrA_C domain of the Plasmodium falciparum antigen. As the trimeric structure of the $\mathrm{S}$ protein, its $\mathrm{C} 1 \mathrm{q}$ domains were able to bind complement receptor 1 in the red blood cell membrane.

Other viral proteins contain $\mathrm{Clq}$ domains as well. They lack a trimer structure, however, and thus cannot be used for cell invasion. C1q stimulates $\mathrm{C} 3$ cleavage, activating the complement system. As a result, other viral proteins' $\mathrm{Clq}$ domains may interfere with or activate the complement system.

The MACPF domain (IPR020864) is a membrane attack complex/perforin (MACPF) family component. The constituent elements interact sequentially and exhibit a high specificity in response to pathogen infection to form a transmembrane channel known as the membrane attack complex (MAC). MACPF has a low sequence similarity. Plasmodium's sporozoite microfilament protein contains the MACPF domain. It is required for cell division 2 (SPECT2). Table 5 shows MACPF domains are found in structural proteins ( $\mathrm{S}, \mathrm{E}, \mathrm{M}$, and $\mathrm{N}$ ) and non-structural proteins (ORF3a, ORF6, ORF7a, ORF7b, ORF8, ORF10, and ORF1ab).

The MACPF domain is frequently found in conjunction with other $\mathrm{N}$ - and C-terminal domains, including TSP1, LDLRA, EGF-like, Sushi/CCP/SCR, FIMAC, and C2. They are in charge of the MACPF function. Oligomerization of the MACPF domain is required for cleavage activity. As shown in Table 6, E, nsp2, nsp10, 3C-like, and exonuclease lack domains that aid MACPF. Therefore, E, nsp2, nsp10, 3C-like, and exonuclease cannot function as MACPF. ORF3a 
and ORF8 protein dimers can form ion channels, as can S protein trimers. So the S, ORF3a, and ORF8 proteins' MACPF domains could form membrane attack complexes.

\subsection{Thiol-activated cytolysin domain}

Cytolysin activated with thiols is capable of dissolving cholesterol-containing membranes. When the domain is reversibly inactivated, it is unable to bind to cholesterol. The Thiol_cytolys_C proteins contain a cysteine residue(100) at the C-terminus of cytolysin, required for cholesterol binding(101). Cholesterol is a necessary component of the membranes of red blood cells.But cholesterol may not be required for viral proteins to make their initial contact with red blood cells. We downloaded proteins involved in hemolysis from the UniProt database. We compared them to viral proteins to identify domains conserved in thiol-activated cytolysin (Table 7).

According to Table 7, structural proteins ( $\mathrm{S}, \mathrm{E}$, and $\mathrm{N}$ ) and non-structural proteins (ORF3a, ORF6, ORF7a, ORF7b, ORF8, ORF10, and nsp3) contain thiol-activated cytolysin domains (Thiol_cytolys_C, IPR035390). This cytolysin domain is absent from the M protein. As shown in Table 7, the Thiol_cytolys_C motifs of S, N, ORF6, ORF10, and nsp3 lack cysteine (C), indicating that they lack thiol-activated cytolysin activity. "CAYCC" refers to the E protein's non-transmembrane heme-binding domain. E's Thiol_cytolys_C motif contains the heme-binding domain. $\mathrm{E}$ is capable of forming pores in the membranes of viruses and infected cells (multi-inclusion bodies). Then $\mathrm{E}$ cannot puncture the membranes of uninfected red blood cells directly. ORF7a and ORF7b have cysteine-containing Thiol_cytolys_C motifs, with ORF7a having an unusually short motif. There is no evidence that these two proteins can form pores. Therefore, these two proteins cannot function as cytolysins.

ORF3a has longer Thiol_cytolys_C motifs. It can all be combined to form dimmers and tetramers. Multimers can be used to construction ion channels. As a result, ORF3a possess cytolysin activity that is activated by thiols. We discovered that ORF3a's "YFLQSINFVRIIMRLWLCWKCRSKNPLLYDANYFLCWHTNCYDYCIPYN" (residues 113-161) contains the B30.2/SPRY domain structure (IPR001870). The SPRY domain is present in the calcium release channel of ryanodine receptors in mammals(101). The protein's SPRY domain is homologous to their respective Thiol_cytolys_C domains. It indicates that the thiol activated cytolysin-built pores in ORF3a acts as calcium release channels. Calcium is required for blood clotting. ORF3a generates pore via Thiol-cytolys hemolysin. The clotting factor calcium ions are released by the SPRY domain regulates the hemolysis of red blood cells. Thiol-activated cytolysins are cholesterol-dependent cytolysins. It is oxygen-sensitive, and its activity is reduced when the oxygen supply is constant or high. So the hemolysin domain of ORF3a is active only in the presence of hypoxia.

\subsection{Viral proteins binds to band 4.1 and spectrin protein on the red blood cell membrane}

From the UniProt database, we downloaded glycophorin-related proteins. We then used the MEME local version tool to compare them one by one to viral proteins in order to identify conserved domains. Table 8 summarizes the results of combining the motifs by protein and domain. According to Table 8, the viral proteins had a $4.1 \mathrm{~m}$ domain. The Band 4.1 protein is a two-subunit globular protein. It acts as a promoter of spectrin-actin binding in the membrane skeleton by binding to spectrin. The $4.1 \mathrm{~m}$ domain can interact with the red blood cell membrane's 4.1 protein. $4.1 \mathrm{~m}$ domains are also found in neurexins, syndecans, and glycophorin C. Syndecan-4 
is a heparan sulfate-containing transmembrane proteoglycan. It is a co-receptor for cell adhesion with integrin. As a result, the SARS-CoV-2 protein can also adhere to the red blood cell membrane via the heparin system. As is shown in Table $8,4.1 \mathrm{~m} \mathrm{~A}$ is in the $\mathrm{S} 1$ protein's N-terminal domain and is involved in receptor binding. S $4.1 \mathrm{~m} \mathrm{B-D}$ is on the S2 protein's transmembrane and outer membrane side and is involved in membrane fusion. It demonstrates that the $\mathrm{S}$ protein bends the erythrocyte membrane via its heparin-like domain. Through the $4.1 \mathrm{~m}$ domain, $\mathrm{S}$ is anchored to band 4.1. ORF3a created pores in the membrane of the host cell. ORF3a $4.1 \mathrm{~m} \mathrm{~A}$ is located outside the transmembrane zone and contains the "CWKCR" heme-binding region. ORF3a is bound to band 4.1 via the $4.1 \mathrm{~m}$ domain. RdRP is a $4.1 \mathrm{~m}$-domain-containing membrane-bound protein RNA polymerase. It shows that the virus will replicate itself using immature red blood cells after infection.

We downloaded the proteins associated with "Erythrocyte membrane protein" from the UniProt database. We then used the MEME local version tool to compare them one by one to the viral proteins to identify conserved domains. We combined the motifs by protein and domain. As shown in Table 9, the E, ORF3a, ORF7a, ORF7b, and ORF8 proteins all contain the Band_3_cyto domain (IPR013769). Band_3_cyto is the cytoplasmic domain of the Band 3 anion exchange protein, which is responsible for the exchange of $\mathrm{Cl}-\mathrm{HCO} 3$ - ions. Band 3's cytoplasmic domain serves primarily as a docking site for other membrane-associated proteins. Ankyrin, protein 4.2, protein 4.1, and hemoglobin are all protein ligands for cdb3. E has a shorter Band_3_cyto domain that serves as the heme-binding domain. Band_3_cyto domains are absent from the S and $\mathrm{M}$ proteins. ORF7a and ORF7b have Band_3_cyto domains that overlap with their $4.1 \mathrm{~m}$ domains, respectively. ORF3a have Band_3_cyto domains that are in or near the transmembrane region. The search results for "Erythrocyte membrane protein"-related proteins also indicates that the $\mathrm{M}$ protein contains a FERM domain (residues 20-130, 178-216). F is an abbreviation for 4.1 protein. 4.1 proteins are associated with spectrin.

The S, N, M, E, and RdRP can all be anchored to the red blood cell membrane, as shown in Tables 8 and 9. It means that immature red blood cells can function as factories for virus synthesis. Synthetic structural proteins (S, M, and E) are on the red blood cell membrane through the intracellular transport system. The $\mathrm{N}$ and RNA complexes are then transported to the membrane of the red blood cell via the intracellular transport system, assembled into a virus, and secreted. The immature red blood cells synthesize heme, so the viral structure proteins such as $\mathrm{S}$ and $\mathrm{E}$ can bind heme(102). The porphyrin complex could enhance the virus's membrane penetration and generate reactive oxygen species (ROS). ORF3a could attack the hemoglobin once it invaded mature red blood cells(102).

\subsection{The invasion mechanism of red blood cells}

The crystal structure file for S protein (PDBID: 6xlu) was downloaded from the PDB database. The domains such as Plasmodium antigen were then annotated. TryThrA_C A-C is located in the virus's extracellular region, as illustrated in Figure 1. TryThrA_C D is found both across the viral membrane and within the viral intracellular. The residue corresponding to the TryThrA_C A part is "ESEFRVYS" due to the truncation of 6xlu. "ESEFR" is the overlapping residue between TryThrA_C A and C1q A. 4.1m A overlaps residue "ESE" in the TryThrA_C A segment. The TryThrA_C A region aids the virus in locating and binding to the membrane of the red blood cell. S first binds to the complement receptor 1 on the red membrane before invading and anchoring the 4.1 protein. The TryThrA_C B-C region aids the virus in its continued invasion 
of red blood cells. The TryThrA_C D region assists $\mathrm{S}$ in inserting into the red blood cell membrane, binding to the 4.1 protein, and forming a membrane fusion channel.

We obtained the crystal structures of ORF3a (PDBID: 6xdc) proteins from the Protein Data Bank. The domains such as malaria parasite antigens were then annotated (Figure 2). The TryThrA_C A of ORF3a is shown in Figure 2.A in the transmembrane alpha-helix and beta folding region. TryThrA_C B denotes the beta fold region on the membrane's surface. EBA-175 VI A overlaps with TryThrA_C A, near the transmembrane's inner side. Thiol_cytolys C of ORF3a is in the transmembrane region and overlaps with EBA-175 VI A, as illustrated in Figure 2.B. The Thiol_cytolys_C region contains domains Band_3_cyto and $4.1 \mathrm{~m}$. Via the TryThrA_C A and TryThrA_C B domains, ORF3a invades the erythrocyte. ORF3a binds to erythrocyte membrane glycoprotein A via the transmembrane EBA-175 antigen, as illustrated in Figure 2.A-B. Simultaneously, the Band_3_cyto and $4.1 \mathrm{~m}$ domains are anchored to the 4.1 protein of red blood cell membrane. Finally, Thiol_cytolys_C establishes calcium ion efflux channels on the membrane of red blood cells.

According to the research mentioned above, the mechanism that viral proteins infect red blood cells may be clarified. Through the tryptophan-threonine-rich Plasmodium antigen (TryThrA), the S protein, ORF3a proteins invaded red blood cells. S protein TryThrA exhibited C1q activity, whereas ORF3a TryThrA exhibited EBA-175 activity. Through the C1q domain, the $\mathrm{S}$ protein was bound to the complement receptor 1 on the red blood cell membrane. ORF3a EBA-175 domains were bound to glycophorin A on the red blood cell membrane. S protein, ORF3a are all bound to band 4.1 and anchor to the skeleton of the red blood cell membrane. Through the MACPF domain, the S protein creates a fusion hole in the red blood cell membrane, injecting viral genetic material into the red blood cell. Through the ion channel constructed by the S protein, the SARS-COV-2 virus injected calcium ions from the virus to the membrane fusion area(66). By using thiol-activated cytolysin, ORF3a created a pore in the erythrocyte membrane. These pores contained ryanodine receptors activity and were capable of releasing calcium ions from within red blood cells. Calcium ion was a factor in blood clotting. As a result, the entry of viral proteins into the red blood cell would not result in a significant hemolytic reaction. Besides, EBA-175 was associated with blood type A. The Knops blood group system was based on a glycoprotein antigen (i.e., CR1 or CD35, complex immune receptor). So blood cells from people with blood type A and Knops were susceptible to infection by the SARS-COV-2 virus.

\subsection{Autotransporter was used to secrete viral proteins from infected cells}

We downloaded the proteins associated with "Autotransporter" from the UniProt database. We then used the MEME local version tool to compare them one by one to the viral proteins to identify conserved domains. We combined the motifs by protein and domain. Table 10 shows structural proteins (S, N, E, and M) and non-structural proteins (ORF3a, ORF8, ORF7a, ORF7b, ORF6, ORF10, nsp2, nsp3, RdRP, and 3'-to-5' Exonuclease) almost all have longer autotransporter domain (SSF103515, IPR036709, IPR005546), except some ORF1ab sub-proteins. On a sequence-wide scale, S, N, M, ORF3a, ORF7a, and ORF8 almost all possess the autotransporter domain. It indicates that SARS-COV-2-infected cells secrete viral proteins into the blood and surrounding tissues via autotransporter. Therefore, ORF3a proteins could enter the blood and invade red blood cells. 


\section{Discussion}

\subsection{The oxygen dissociation curve was insufficiently interpretable}

The heme theory found through calculations that ORF3a would attack hemoglobin(102). Some perplexing signs are now regarding oxygen supply and hemolysis in COVID-19 patients whose red blood cells are attacked. COVID-19 patients are still able to dance and sing despite low blood oxygen saturation. However, this situation will not last long, and as a result, hypoxia will worsen, and the condition will deteriorate rapidly. It is referred to as the "happy hypoxia paradox"(103). The $\mathrm{Hb}$ oxygen dissociation curve represents the relationship between blood oxygen partial pressure and hemoglobin oxygen saturation. P50 denotes the oxygen partial pressure at which hemoglobin is $50 \%$ oxygen saturated. When the oxygen affinity of hemoglobin increases, the dissociation curve of oxyhemoglobin shifts to the left. It lowers P50, thereby decreasing tissue oxygen delivery. It has been reported that in some COVID-19 patients, the oxygen dissociation curve does not shift to the left or right(104). The mixed-effects model (with $\mathrm{pH}$ and $\mathrm{PCO} 2$ as covariates) revealed that SARS-CoV2 had a small but significant effect on the $\mathrm{PO} / \mathrm{SO} 2$ relationship and appeared to be less sensitive to PCO2 in COVID-19 patients(105). In comparison to other pneumonia patients, there is no evidence of hemolysis. These researchers believe that there has been no significant change in hemoglobin's oxygen-carrying capacity(106). That hemoglobin's affinity for oxygen has remained constant(107). The problem is referred to as the "oxygen dissociation curve problem." The oxygen affinity of hemoglobin in COVID-19 patients are the subjects of intense academic debate(108).

However, structural proteins in COVID-19 patients' red blood cells were significantly damaged(35). At the same time, membrane lipid remodeling and the level of RBC glycolysis intermediates increased(35). There are no significant changes in blood parameters such as RBC count, hematocrit or average corpuscular hemoglobin concentration, or average corpuscular volume(35). Notably, an increase in RDW correlates with a decrease in ventilator-free days in the intensive care unit (109). As the severity of COVID-19 increases, the distribution width of red blood cells (RDW) gradually increases(110). The phenomenon is defined by the apparent heterogeneity of red blood cell volume(111). Numerous studies have revealed that some COVID-19 patients do experience significant hemolysis problems. There is a need for a more rational method of evaluating the hemoglobin affinity argument, particularly at the microcirculation level(112). Microscopic spectrophotometry analysis revealed a significant shift in a single COVID-19 patient's red blood cell(113). Hemoglobin absorbance increases in the $420 \mathrm{~nm}$ wavelength range during severe SARS-CoV-2 infections(113).

In patients with hypoxia, this study discovered that cholesterol-dependent cytolysin activated its hemolysis function. According to some studies on the "oxygen dissociation curve problem," COVID-19 patients exhibit no obvious signs of hypoxia or hemolysis. It indicated that specific SARS-CoV-2 proteins contained cholesterol-dependent cytolysins. Their hemolytic activity was also related to the availability of oxygen. In hypoxia, it induced hemolysis. Calcium ions are involved in the process of red blood cell invasion. Calcium ion is a factor in blood clotting. As a result, viral proteins may not cause a significant hemolytic reaction when they enter the red blood cell membrane. This study discovered that the viral proteins $\mathrm{S}$ and ORF3a contain a $4.1 \mathrm{~m}$ domain that binds to 4.1 protein in the red blood cell membrane. $4.1 \mathrm{~m}$ domains are also found in neurexins, syndecans, and glycophorin C. Syndecan-4 is a heparan sulfate-containing transmembrane 
proteoglycan. It functions as a co-receptor for cell adhesion with integrin. As a result, the SARS-CoV-2 protein can also adhere to the red blood cell membrane via the heparin system. Glycophorin C (GPC) and Glycophorin D (GPD) both express antigens from the Gerbich blood group system(20). Generally, Gerbich antibodies do not result in severe hemolytic reactions. As a result, some researchers believe that excessive interpretation of the oxygen dissociation curve is inappropriate(114). If the oxygen dissociation curve is used exclusively in medical diagnosis, it may result in an error. It is worth noting that our discovered malaria had comparable hemolysis and oxygen supply issues.

\subsection{The 2,3-diphosphoglycerate (BPG) augmented hemoglobin's oxygen-supply function}

Hemoglobin levels are significantly lower in patients infected with Plasmodium vivax and Plasmodium falciparum than those with negative reactions(44). When widespread anemia occurs, oxygen delivery to tissues may be further compromised(115). However, parasitemia is not associated with anemia in patients infected with Plasmodium vivax or Plasmodium falciparum (44). Antibodies against red blood cells and anticardiolipin are not associated with the presence or severity of anemia(44). 2,3-diphosphoglycerate (BPG) interacts with hemoglobin molecules to increase P50, thereby promoting oxygen release. Metabolic acidosis is a significant predictor of hemoglobin-oxygen dissociation in severe childhood Plasmodium falciparum malaria(116). Acidosis, such as the excruciating pain associated with diabetic ketoacidosis(117), can impair BPG synthesis(118). There is a decrease in BPG in animals with severe malaria, according to studies(119). After the BPG concentration decreases, the oxygen dissociation curve shifts to the left(120). COVID-19 patients have active erythrocyte glycolysis(35). It was not ruled out that the BPG enhanced hemoglobin's oxygen-supply function in damaged erythrocytes(121).

\subsection{The hemoglobin phenotype affected the blood's oxygen transport}

Anemia and the hemoglobin phenotype have an effect on $\mathrm{O} 2$ transport in the blood during malaria infection. Infected red blood cells transport $\mathrm{O} 2$ in a fraction of how uninfected cells do (122). Raman spectral changes in Plasmodium vivax-infected blood samples indicate a decrease in oxygen affinity(123). Intracellular hemoglobin's oxygen dissociation curve shifts to the right(123). The Bohr effect is a phenomenon that occurs when the concentration of $\mathrm{CO} 2$ in the blood decreases, lowering the intracellular $\mathrm{pH}$ and lowering the oxygen affinity of hemoglobin in red blood cells. The experiment found there is no significant difference in the oxygen affinity of erythrocyte hemolysates containing $\mathrm{Hb}-\mathrm{S}$ and $\mathrm{Hb}-\mathrm{A}$ following potassium phosphate buffer dialysis(124). The oxygen affinity of homozygous $\mathrm{Hb}-\mathrm{C}$ and $\mathrm{Hb}-\mathrm{E}$ carriers appears to be comparable to that of standard blood samples and erythrocyte lysates. When Hb-D with an abnormal chain is compared to a fraction of Hb-A separated, the Bohr effect remains unchanged. $\mathrm{Hb}$ - purified using CM-cellulose or DEAE-cellulose chromatography has a significantly higher affinity for molecular oxygen than normal $\mathrm{Hb}$-A. The Bohr effect and the heme-heme interaction are identical. Patients with HbE-thalassemia can adapt to anemia by lowering their red blood cells' oxygen affinity. The presence of a high concentration of 2,3-BPG reduces the oxygen affinity to compensate for the high affinity of $\mathrm{HbF}$. Heterozygosity hemoglobin is partially protective against Plasmodium falciparum. It facilitates the clearance of infected red blood cells by host immune effectors such as macrophages(125). Then, patients are less likely to develop potentially fatal cerebral malaria or severe anemia(125). Of course, other factors such as the initial infection dose, 
nutrition, co-infection, and genetics can be considered(126). The interaction between erythropoietin and hemoglobin levels does not appear to be directly related to the P50 value in these cases(127). When the SARS-COV-2 virus infects red blood cells or ORF3a invades red blood cells, a similar Bohr effect or anemia occurs as well.

\section{Conclusion}

Malaria symptoms are very similar to those of COVID-19, and infections can be symptomatic or asymptomatic. Common immunodominant epitopes exist between the SARS-CoV-2 proteins and the Plasmodium falciparum antigen. We used the domain search method to investigate the mechanism of SARS-CoV-2 protein invasion into red blood cells in this present study. S protein was found to be bind to complement receptor 1 on the red blood cell membrane via the C1q domain. ORF3a EBA-175 domains were attached to glycophorin A on the red blood cell membrane. Both domains contained a high concentration of tryptophan threonine Plasmodium antigens. S, ORF3a were linked to band 4.1 respectively, one erythrocyte membrane skeleton protein. Through the MACPF domain, the $\mathrm{S}$ protein formed a fusion channel on the red blood cell membrane. It injected viral genetic material into the mature red blood cell. The $\mathrm{S}$ protein's ion channel injected calcium ions into the virus's membrane fusion region. ORF3a is capable of forming not only dimers but also tetramers. ORF3a employed a thiol-activated cytolysin domain to create hemolytic pores in the red blood cell membrane. As with ryanodine receptors, the channel could release calcium ions from the inside of red blood cells. Calcium ion was a factor in blood clotting. As a result, the viral protein penetrated the red blood cell membrane without inducing significant hemolysis. According to the SARS-COV-2 Plasmodium antigen type, the blood cells of individuals with blood types A and Knops were susceptible to the SARS-COV-2 virus protein attack. It was similar to the blood type infection rule of falciparum malaria.

\section{Declarations}

\section{Ethics approval and consent to participate}

Not applicable.

\section{Consent for publication}

Not applicable.

\section{Availability of data and material}

The datasets and results supporting the conclusions of this article are available at https://pan.baidu.com/s/134YBm07tzItE1cDF-RLVAQ, code: yqg8.

Or: https://mega.nz/folder/1mIhiIJL\#PDsPzO7HW8a1tGIHz2oQVg

\section{Competing interests}

The authors declare that they have no competing interests.

\section{Funding}

This work was funded by a grant from the Talent Introduction Project of Sichuan University of Science and Engineering (award number: 2018RCL20, grant recipient: WZL). 


\section{Author's contribution}

Funding was obtained by WZL. Besides, design, analysis and writing are finished by WZL, while data curation and manuscript check are undertaken by HLL. Both authors have read and agreed to the published version of the manuscript.

\section{Acknowledgements}

Not applicable.

\section{Author details}

${ }^{1}$ School of Computer Science and Engineering, Sichuan University of Science \& Engineering, Zigong, 643002, China.

${ }^{2}$ School of Life Science and Food Engineering, Yibin University, Yibin, 644000, China.

\section{References}

1. Luxemburger, C., K. L. Thwai, N. J. White, H. K. Webster, D. E. Kyle, L. Maelankirri, T. Chongsuphajaisiddhi, and F. Nosten. 1996. The epidemiology of malaria in a Karen population on the western border of Thailand. Transactions of the Royal Society of Tropical Medicine and Hygiene 90: 105-111.

2. Price, R. N., E. Tjitra, C. A. Guerra, S. Yeung, N. J. White, and N. M. Anstey. 2007. Vivax malaria: neglected and not benign. The American journal of tropical medicine and hygiene 77: 79-87.

3. Williams, T. N., K. Maitland, L. Phelps, S. Bennett, T. E. Peto, J. Viji, R. Timothy, J. B. Clegg, D. J. Weatherall, and D. K. Bowden. 1997. Plasmodium vivax: a cause of malnutrition in young children. QJM : monthly journal of the Association of Physicians 90: 751-757.

4. Genton, B., V. D'Acremont, K. Lorry, K. Baea, J. Reeder, and I. Mueller. 2005. Plasmodium vivax is associated with severe malaria in Papua New Guinean children. In AMERICAN JOURNAL OF TROPICAL MEDICINE AND HYGIENE. AMER SOC TROP MED \& HYGIENE 8000 WESTPARK DR, STE 130, MCLEAN, VA 22101 USA. 14-14.

5. Di Gennaro, F., C. Marotta, P. Locantore, D. Pizzol, and G. Putoto. 2020. Malaria and COVID-19: Common and Different Findings. Trop Med Infect Dis 5: 141.

6. Galatas, B., Q. Bassat, and A. Mayor. 2016. Malaria Parasites in the Asymptomatic: Looking for the Hay in the Haystack. Trends Parasitol 32: 296-308.

7. Kishore, R., S. Dhakad, N. Arif, L. Dar, B. Mirdha, R. Aggarwal, and S. Kabra. 2020. COVID-19: Possible cause of induction of relapse of Plasmodium vivax Infection. The Indian Journal of Pediatrics 87: 751-752.

8. Zhu, M., Y. Zhu, J. Zhang, and W. Liu. 2020. A case of COVID-19 with Imported Falciparum Malaria Infection is Reported. Front. Med 21: 1-9.

9. Weiss, G. E., P. R. Gilson, T. Taechalertpaisarn, W. H. Tham, N. W. de Jong, K. L. Harvey, F. J. Fowkes, P. N. Barlow, J. C. Rayner, G. J. Wright, A. F. Cowman, and B. S. Crabb. 2015. Revealing the sequence and resulting cellular morphology of receptor-ligand interactions during Plasmodium falciparum invasion of erythrocytes. PLoS Pathog 11: e1004670.

10. Hondermarck, H., N. W. Bartlett, and V. Nurcombe. 2020. The role of growth factor receptors in viral infections: An opportunity for drug repurposing against emerging viral diseases such as COVID-19? FASEB BioAdvances 2: 296-303. 
11. Crosnier, C., L. Y. Bustamante, S. J. Bartholdson, A. K. Bei, M. Theron, M. Uchikawa, S. Mboup, O. Ndir, D. P. Kwiatkowski, M. T. Duraisingh, J. C. Rayner, and G. J. Wright. 2011. Basigin is a receptor essential for erythrocyte invasion by Plasmodium falciparum. Nature 480: 534-537.

12. Klickstein, L. B., S. F. Barbashov, T. Liu, R. M. Jack, and A. Nicholson-Weller. 1997. Complement receptor type $1(\mathrm{CR} 1, \mathrm{CD} 35)$ is a receptor for C1q. Immunity $7: 345-355$.

13. Crosnier, C., L. Y. Bustamante, S. J. Bartholdson, A. K. Bei, M. Theron, M. Uchikawa, S. Mboup, O. Ndir, D. P. Kwiatkowski, and M. T. Duraisingh. 2011. Basigin is a receptor essential for erythrocyte invasion by Plasmodium falciparum. Nature 480: 534-537.

14. Spring, F. A., C. H. Holmes, K. L. Simpson, W. J. Mawby, M. Jules Mattes, Y. Okubo, and S. F. Parsons. 1997. The Oka blood group antigen is a marker for the M6 leukocyte activation antigen, the human homolog of OX-47 antigen, basigin and neurothelin, an immunoglobulin superfamily molecule that is widely expressed in human cells and tissues. European journal of immunology 27: 891-897.

15. Mitchell, G., A. Thomas, G. Margos, A. Dluzewski, and L. Bannister. 2004. Apical membrane antigen 1, a major malaria vaccine candidate, mediates the close attachment of invasive merozoites to host red blood cells. Infection and immunity 72: 154-158.

16. Rusmini, M., P. Uva, A. Amoroso, M. Tolomeo, and A. Cavalli. 2021. How Genetics Might Explain the Unusual Link Between Malaria and COVID-19. Frontiers in Medicine 8.

17. Tanabe, K., T. Mita, T. Jombart, A. Eriksson, S. Horibe, N. Palacpac, L. Ranford-Cartwright, H. Sawai, N. Sakihama, and H. Ohmae. 2010. Plasmodium falciparum accompanied the human expansion out of Africa. Current Biology 20: 1283-1289.

18. Gelabert, P., I. Olalde, T. de-Dios, S. Civit, and C. Lalueza-Fox. 2017. Malaria was a weak selective force in ancient Europeans. Scientific reports 7: 1-10.

19. Jaskiewicz, E., M. Jodłowska, R. Kaczmarek, and A. Zerka. 2019. Erythrocyte glycophorins as receptors for Plasmodium merozoites. Parasites \& Vectors 12: 317.

20. Jaskiewicz, E., T. Peyrard, R. Kaczmarek, A. Zerka, M. Jodlowska, and M. Czerwinski. 2018. The Gerbich blood group system: old knowledge, new importance. Transfusion medicine reviews 32: 111-116.

21. Baldwin, M. R., X. Li, T. Hanada, S. C. Liu, and A. H. Chishti. 2015. Merozoite surface protein 1 recognition of host glycophorin A mediates malaria parasite invasion of red blood cells. Blood 125: 2704-2711.

22. Orlandi, P. A., F. W. Klotz, and J. D. Haynes. 1992. A malaria invasion receptor, the 175-kilodalton erythrocyte binding antigen of Plasmodium falciparum recognizes the terminal Neu5Ac(alpha 2-3)Galsequences of glycophorin A. J Cell Biol 116: 901-909.

23. Zhao, J., Y. Yang, H. Huang, D. Li, D. Gu, X. Lu, Z. Zhang, L. Liu, T. Liu, and Y. Liu. 2021. Relationship between the ABO blood group and the coronavirus disease 2019 (COVID-19) susceptibility. Clinical Infectious Diseases 73: 328-331.

24. Java, A., A. J. Apicelli, M. K. Liszewski, A. Coler-Reilly, J. P. Atkinson, A. H. Kim, and H. S. Kulkarni. 2020. The complement system in COVID-19: friend and foe? JCI insight 5.

25. Cheng, Y., G. Cheng, C. H. Chui, F. Y. Lau, P. K. Chan, M. H. Ng, J. J. Sung, and R. S. Wong. 2005. ABO blood group and susceptibility to severe acute respiratory syndrome. Jama 293: 1450-1451.

26. Iesa, M. A., M. E. Osman, M. A. Hassan, A. I. Dirar, N. Abuzeid, J. J. Mancuso, R. Pandey, A. A. Mohammed, M. J. Borad, and H. M. Babiker. 2020. SARS-CoV-2 and Plasmodium falciparum common immunodominant regions may explain low COVID-19 incidence in the malaria-endemic belt. New microbes and new infections 38: 100817. 
27. Miller, L. H., S. J. Mason, D. F. Clyde, and M. H. McGinniss. 1976. The resistance factor to Plasmodium vivax in blacks. The Duffy-blood-group genotype, FyFy. The New England journal of medicine 295: 302-304.

28. Mourão, L. C., R. d. P. Baptista, Z. B. de Almeida, P. Grynberg, M. M. Pucci, T. Castro-Gomes, C. J. F. Fontes, S. Rathore, Y. D. Sharma, R. A. da Silva-Pereira, M. P. Bemquerer, and É. M. Braga. 2018. Anti-band 3 and anti-spectrin antibodies are increased in Plasmodium vivax infection and are associated with anemia. Scientific Reports 8: 8762.

29. Ménard, D., C. Barnadas, C. Bouchier, C. Henry-Halldin, L. R. Gray, A. Ratsimbasoa, V. Thonier, J. F. Carod, O. Domarle, Y. Colin, O. Bertrand, J. Picot, C. L. King, B. T. Grimberg, O. Mercereau-Puijalon, and P. A. Zimmerman. 2010. Plasmodium vivax clinical malaria is commonly observed in Duffy-negative Malagasy people. Proceedings of the National Academy of Sciences of the United States of America 107: 5967-5971.

30. Zeeshan, M., R. K. Tyagi, K. Tyagi, M. S. Alam, and Y. D. Sharma. 2015. Host-parasite interaction: selective Pv-fam-a family proteins of Plasmodium vivax bind to a restricted number of human erythrocyte receptors. The Journal of infectious diseases 211: 1111-1120.

31. Curtidor, H., M. Ocampo, L. Rodríguez, R. López, J. García, J. Valbuena, R. Vera, A. Puentes, J. Leiton, L. J. Cortés, Y. López, and M. Patarroyo. 2006. Plasmodium falciparum TryThrA antigen synthetic peptides block in vitro merozoite invasion to erythrocytes. Biochemical and biophysical research communications 3393 : 888-896.

32. Tyagi, R. K., and Y. D. Sharma. 2012. Erythrocyte Binding Activity Displayed by a Selective Group of Plasmodium vivax Tryptophan Rich Antigens Is Inhibited by Patients' Antibodies. PLoS One 7: e50754.

33. Rathore, S., S. Dass, D. Kandari, I. Kaur, M. Gupta, and Y. D. Sharma. 2017. Basigin interacts with Plasmodium vivax tryptophan-rich antigen PvTRAg38 as a second erythrocyte receptor to promote parasite growth. Journal of Biological Chemistry 292: 462-476.

34. Alam, M. S., V. Choudhary, M. Zeeshan, R. K. Tyagi, S. Rathore, and Y. D. Sharma. 2015. Interaction of Plasmodium vivax Tryptophan-rich Antigen PvTRAg38 with Band 3 on Human Erythrocyte Surface Facilitates Parasite Growth. The Journal of biological chemistry 290: 20257-20272.

35. Thomas, T., D. Stefanoni, M. Dzieciatkowska, A. Issaian, T. Nemkov, R. C. Hill, R. O. Francis, K. E. Hudson, P. W. Buehler, J. C. Zimring, E. A. Hod, K. C. Hansen, S. L. Spitalnik, and A. D'Alessandro. 2020. Evidence of Structural Protein Damage and Membrane Lipid Remodeling in Red Blood Cells from COVID-19 Patients. J Proteome Res 19: 4455-4469.

36. Schibli, D. J., R. C. Montelaro, and H. J. Vogel. 2001. The membrane-proximal tryptophan-rich region of the HIV glycoprotein, gp41, forms a well-defined helix in dodecylphosphocholine micelles. Biochemistry 40: 9570-9578.

37. Divita, G., J. G. Baillon, K. Rittinger, J. C. Chermann, and R. S. Goody. 1995. Interface peptides as structure-based human immunodeficiency virus reverse transcriptase inhibitors. The Journal of biological chemistry 270: 28642-28646.

38. Salzwedel, K., J. T. West, and E. Hunter. 1999. A conserved tryptophan-rich motif in the membrane-proximal region of the human immunodeficiency virus type 1 gp41 ectodomain is important for Env-mediated fusion and virus infectivity. $J$ Virol 73: 2469-2480.

39. Komla-Soukha, I., and C. Sureau. 2006. A tryptophan-rich motif in the carboxyl terminus of the small envelope protein of hepatitis B virus is central to the assembly of hepatitis delta virus particles. $J$ Virol 80: 4648-4655.

40. Li, M. L., P. Rao, and R. M. Krug. 2001. The active sites of the influenza cap-dependent endonuclease are on different polymerase subunits. Embo j 20: 2078-2086. 
41. Abbate, J., P. Becquart, E. Leroy, V. Ezenwa, and B. Roche. 2020. Exposure to Ebola Virus and Risk for Infection with Malaria Parasites, Rural Gabon. Emerging Infectious Disease journal 26: 229.

42. Pye, D., S. J. Edwards, R. F. Anders, C. M. O'Brien, P. Franchina, L. N. Corcoran, C. Monger, M. G. Peterson, K. L. Vandenberg, J. A. Smythe, and et al. 1991. Failure of recombinant vaccinia viruses expressing Plasmodium falciparum antigens to protect Saimiri monkeys against malaria. Infect Immun 59: 2403-2411.

43. Xiao, L., S. M. Owen, D. L. Rudolph, R. B. Lal, and A. A. Lal. 1998. Plasmodium falciparum antigen-induced human immunodeficiency virus type 1 replication is mediated through induction of tumor necrosis factor-alpha. $J$ Infect Dis 177: 437-445.

44. Fernandes, A. A. M., L. J. d. M. Carvalho, G. M. Zanini, A. M. R. d. S. Ventura, J. M. Souza, P. M. Cotias, I. L. Silva-Filho, and C. T. Daniel-Ribeiro. 2008. Similar Cytokine Responses and Degrees of Anemia in Patients with $<\mathrm{i}>$ Plasmodium falciparum $</ \mathrm{i}>$ and $<\mathrm{i}>$ Plasmodium vivax $</ \mathrm{i}>$ Infections in the Brazilian Amazon Region. Clinical and Vaccine Immunology 15: 650-658.

45. Lapidus, S., F. Liu, and A. Casanovas-Massana. 2021. Plasmodium infection induces cross-reactive antibodies to carbohydrate epitopes on the SARS-CoV-2 Spike protein. medRxiv: 2021.2005.2010.21256855.

46. El-Shamy, A., A. D. Branch, T. D. Schiano, and P. D. Gorevic. 2018. The Complement System and C1q in Chronic Hepatitis C Virus Infection and Mixed Cryoglobulinemia. Frontiers in Immunology 9.

47. Spear, G. T., H. Jiang, B. L. Sullivan, H. GewÜRz, A. L. Landay, and T. F. Lint. 1991. Direct Binding of Complement Component C1q to Human Immunodeficiency Virus (HIV) and Human T Lymphotrophic Virus-I (HTLV-I) Coinfected Cells. AIDS Research and Human Retroviruses 7: 579-585.

48. Mehlhop, E., C. Ansarah-Sobrinho, S. Johnson, M. Engle, D. H. Fremont, T. C. Pierson, and M. S. Diamond. 2007. Complement protein $\mathrm{C} 1 \mathrm{q}$ inhibits antibody-dependent enhancement of flavivirus infection in an $\operatorname{IgG}$ subclass-specific manner. Cell host \& microbe 2: 417-426.

49. Furuyama, W., A. Nanbo, J. Maruyama, A. Marzi, and A. Takada. 2020. A complement component C1q-mediated mechanism of antibody-dependent enhancement of Ebola virus infection. PLOS Neglected Tropical Diseases 14: e0008602.

50. Koma, T., V. Veljkovic, and D. E. Anderson. 2018. Zika virus infection elicits auto-antibodies to C1q. Scientific Reports 8: 1882.

51. Douradinha, B., S. P. McBurney, K. M. S. de Melo, A. P. Smith, N. K. Krishna, S. M. Barratt-Boyes, J. D. Evans, E. J. Nascimento, and E. T. Marques Jr. 2014. C1q binding to dengue virus decreases levels of infection and inflammatory molecules transcription in THP-1 cells. Virus research 179: 231-234.

52. Fox, S. E., A. Akmatbekov, J. L. Harbert, G. Li, J. Quincy Brown, and R. S. Vander Heide. 2020. Pulmonary and cardiac pathology in African American patients with COVID-19: an autopsy series from New Orleans. The Lancet. Respiratory medicine 8: 681-686.

53. Gralinski, L. E., T. P. Sheahan, T. E. Morrison, V. D. Menachery, K. Jensen, S. R. Leist, A. Whitmore, M. T. Heise, and R. S. Baric. 2018. Complement Activation Contributes to Severe Acute Respiratory Syndrome Coronavirus Pathogenesis. mBio 9.

54. Ma, L., S. K. Sahu, M. Cano, V. Kuppuswamy, J. Bajwa, A. Pine, M. L. Meizlish, G. Goshua, C.-H. Chang, and H. Zhang. 2021. Increased complement activation is a distinctive feature of severe SARS-CoV-2 infection. Science Immunology 6.

55. Chouaki Benmansour, N., J. Carvelli, and E. Vivier. 2021. Complement cascade in severe forms of COVID-19: Recent advances in therapy. European Journal of Immunology 51: 1652-1659.

56. Lo, M. W., C. Kemper, and T. M. Woodruff. 2020. COVID-19: Complement, Coagulation, and Collateral Damage. The Journal of Immunology 205: 1488-1495. 
57. Shen, B., X. Yi, Y. Sun, X. Bi, J. Du, C. Zhang, S. Quan, F. Zhang, R. Sun, L. Qian, W. Ge, W. Liu, S. Liang, H. Chen, Y. Zhang, J. Li, J. Xu, Z. He, B. Chen, J. Wang, H. Yan, Y. Zheng, D. Wang, J. Zhu, Z. Kong, Z. Kang, X. Liang, X. Ding, G. Ruan, N. Xiang, X. Cai, H. Gao, L. Li, S. Li, Q. Xiao, T. Lu, Y. Zhu, H. Liu, H. Chen, and T. Guo. 2020. Proteomic and Metabolomic Characterization of COVID-19 Patient Sera. Cell 182: 59-72.e15.

58. Kulkarni, H. S., M. K. Liszewski, S. L. Brody, and J. P. Atkinson. 2018. The complement system in the airway epithelium: An overlooked host defense mechanism and therapeutic target? Journal of Allergy and Clinical Immunology 141: 1582-1586. e1581.

59. Wilk, C. M. 2020. Coronaviruses hijack the complement system. Nature Reviews Immunology 20: 350-350.

60. Gao, T., M. Hu, X. Zhang, H. Li, L. Zhu, H. Liu, Q. Dong, Z. Zhang, Z. Wang, and Y. Hu. 2020. Highly pathogenic coronavirus $\mathrm{N}$ protein aggravates lung injury by MASP-2-mediated complement over-activation. MedRxiv.

61. Yu, J., X. Yuan, H. Chen, S. Chaturvedi, E. M. Braunstein, and R. A. Brodsky. 2020. Direct activation of the alternative complement pathway by SARS-CoV-2 spike proteins is blocked by factor D inhibition. Blood 136: 2080-2089.

62. Stoermer, K. A., and T. E. Morrison. 2011. Complement and viral pathogenesis. Virology 411: 362-373.

63. Liszewski, M. K., P. Bertram, M. K. Leung, R. Hauhart, L. Zhang, and J. P. Atkinson. 2008. Smallpox inhibitor of complement enzymes (SPICE): regulation of complement activation on cells and mechanism of its cellular attachment. J Immunol 181: 4199-4207.

64. Tam, J. C., S. R. Bidgood, W. A. McEwan, and L. C. James. 2014. Intracellular sensing of complement C3 activates cell autonomous immunity. Science 345: 1256070.

65. Ishino, T., Y. Chinzei, and M. Yuda. 2005. A Plasmodium sporozoite protein with a membrane attack complex domain is required for breaching the liver sinusoidal cell layer prior to hepatocyte infection. Cellular microbiology 7: 199-208.

66. Wenzhong, L., and L. Hualan. 2021. COVID-19: the CaMKII-like system of S protein drives membrane fusion and induces syncytial multinucleated giant cells. Immunologic Research.

67. Norrby, E. C. J., and L. G. Falksveden. 1964. Some general properties of the measles virus hemolysin. Archiv für die gesamte Virusforschung 14: 474-486.

68. Devireddy, L., R. Raghavan, S. Ramachandran, and M. Shaila. 1999. The fusion protein of peste des petits ruminants virus is a hemolysin. Archives of virology 144: 1241-1247.

69. Faddoul, E. M. 1967. The kinetics of the hemolysin of Newcastle disease virus. Iowa State University.

70. Bratt, M. A., and L. A. Clavell. 1972. Hemolytic interaction of Newcastle disease virus and chicken erythrocytes. I. Quantitative comparison procedure. Applied microbiology 23: 454-460.

71. Karabatsos, N. 1963. Hemolytic Properties of Eastern and Western Equine Encephalomyelitis Viruses. The Journal of Immunology 91: 76-82.

72. Chu, L. W., and H. R. Morgan. 1950. STUDIES OF THE HEMOLYSIS OF RED BLOOD CELLS BY MUMPS VIRUS : I. THE DEVELOPMENT OF MUMPS VIRUS HEMOLYSIN AND ITS INACTIVATION BY CERTAIN PHYSICAL AND CHEMICAL AGENTS. $J$ Exp Med 91: 393-402.

73. Wolff, G., R. W. A. L. Limpens, J. C. Zevenhoven-Dobbe, U. Laugks, S. Zheng, A. W. M. de Jong, R. I. Koning, D. A. Agard, K. Grünewald, A. J. Koster, E. J. Snijder, and M. Bárcena. 2020. A molecular pore spans the double membrane of the coronavirus replication organelle. Science 369: 1395-1398.

74. Kern, D. M., B. Sorum, S. S. Mali, C. M. Hoel, S. Sridharan, J. P. Remis, D. B. Toso, A. Kotecha, D. M. Bautista, and S. G. Brohawn. 2021. Cryo-EM structure of SARS-CoV-2 ORF3a in lipid nanodiscs. Nature Structural \& Molecular Biology: 1-10. 
75. Barrantes, F. 2021. Structural biology of coronavirus ion channels. Acta Crystallographica Section D 77: $391-402$.

76. Alouf, J. E. 2001. Pore-forming bacterial protein toxins: an overview. Pore-forming toxins: 1-14.

77. Murphy, S. C., B. U. Samuel, T. Harrison, K. D. Speicher, D. W. Speicher, M. E. Reid, R. Prohaska, P. S. Low, M. J. Tanner, N. Mohandas, and K. Haldar. 2004. Erythrocyte detergent-resistant membrane proteins: their characterization and selective uptake during malarial infection. Blood 103: 1920-1928.

78. Murphy, S. C., N. L. Hiller, T. Harrison, J. W. Lomasney, N. Mohandas, and K. Haldar. 2006. Lipid rafts and malaria parasite infection of erythrocytes. Molecular membrane biology 23: 81-88.

79. Morimoto, M., and H. R. Morgan. 1954. Effect of Lecithin, Cholesterol and Gardiolipin on Mumps Virus Hemolysin. Proceedings of the Society for Experimental Biology and Medicine 86: 795-800.

80. Heuck, A. P., P. C. Moe, and B. B. Johnson. 2010. The cholesterol-dependent cytolysin family of gram-positive bacterial toxins. Cholesterol Binding and Cholesterol Transport Proteins:: 551-577.

81. Pleckaityte, M. 2020. Cholesterol-Dependent Cytolysins Produced by Vaginal Bacteria: Certainties and Controversies. Front Cell Infect Microbiol 9.

82. Nguyen, B. N., B. N. Peterson, and D. A. Portnoy. 2019. Listeriolysin O: A phagosome-specific cytolysin revisited. Cellular microbiology 21: e12988-e12988.

83. Umashankar, M., C. Sánchez-San Martín, M. Liao, B. Reilly, A. Guo, G. Taylor, and M. Kielian. 2008. Differential cholesterol binding by class II fusion proteins determines membrane fusion properties. Journal of virology 82: 9245-9253.

84. Faisal, H., A. Bloom, and A. O. Gaber. 2020. Unexplained Methemoglobinemia in Coronavirus Disease 2019: A Case Report. A\&A practice 14: e01287-e1287.

85. Lansiaux, E., P. P. Pébaÿ, J.-L. Picard, and J. Son-Forget. 2020. COVID-19: beta-thalassemia subjects immunised? Medical Hypotheses 142: 109827.

86. Balanchivadze, N., A. A. Kudirka, S. Askar, K. Almadhoun, P. Kuriakose, R. Fadel, and V. Dabak. 2020. Impact of COVID-19 Infection on 24 Patients with Sickle Cell Disease. One Center Urban Experience, Detroit, MI, USA. Hemoglobin 44: 284-289.

87. Chaudhry, Z. R., S. Rasheed, S. Shakir, E. Rashid, M. Ansari, and F. Rasheed. 2021. Corona virus lowers hemoglobin more in severe infection than mild COVID-19 infection. The Professional Medical Journal 28: 1211-1214.

88. BANDYOPADHYAY, A. R., D. CHATTERJEE, and K. GHOSH. 2021. HAPTOGLOBIN (HP) POLYMORPHISM AND COVID-19: A REVIEW. Innovat International Journal of Medical \& Pharmaceutical Sciences 6.

89. Ali, N. N., and S. G. Varma. Study of correlation between hemoglobin, ferritn and lactate dehydrogenase in SARS-COVID 19 positive patients at tertiary care hospital.

90. Karimi, M., and V. De Sanctis. 2020. Implications of SARSr-CoV 2 infection in thalassemias: Do patients fall into the "high clinical risk" category? Acta bio-medica : Atenei Parmensis 91: 50-56.

91. Oomen, C. J., P. van Ulsen, P. van Gelder, M. Feijen, J. Tommassen, and P. Gros. 2004. Structure of the translocator domain of a bacterial autotransporter. The EMBO journal 23: 1257-1266.

92. van den Berg, B. 2010. Crystal structure of a full-length autotransporter. Journal of molecular biology 396: 627-633.

93. Pohlner, J., R. Halter, K. Beyreuther, and T. F. Meyer. 1987. Gene structure and extracellular secretion of Neisseria gonorrhoeae IgA protease. Nature 325: 458-462.

94. Henderson, I. R., F. Navarro-Garcia, and J. P. Nataro. 1998. The great escape: structure and function of the autotransporter proteins. Trends in microbiology 6: 370-378. 
95. Chin, G. 2007. Activating En Passant. Science 315: 1638-1638.

96. Sellar, G. C., D. J. Blake, and K. B. Reid. 1991. Characterization and organization of the genes encoding the A-, B- and C-chains of human complement subcomponent C1q. The complete derived amino acid sequence of human C1q. The Biochemical journal 274 ( Pt 2): 481-490.

97. Engel, J., and D. J. Prockop. 1991. The zipper-like folding of collagen triple helices and the effects of mutations that disrupt the zipper. Annu Rev Biophys Biophys Chem 20: 137-152.

98. Kwan, A. P., C. E. Cummings, J. A. Chapman, and M. E. Grant. 1991. Macromolecular organization of chicken type X collagen in vitro. The Journal of cell biology 114: 597-604.

99. Tu, X., and K. Palczewski. 2012. Crystal structure of the globular domain of C1QTNF5: Implications for late-onset retinal macular degeneration. Journal of structural biology 180: 439-446.

100. Geoffroy, C., J. Mengaud, J. E. Alouf, and P. Cossart. 1990. Alveolysin, the thiol-activated toxin of Bacillus alvei, is homologous to listeriolysin $\mathrm{O}$, perfringolysin $\mathrm{O}$, pneumolysin, and streptolysin $\mathrm{O}$ and contains a single cysteine. Journal of bacteriology 172: 7301-7305.

101. Iwamoto, M., Y. Ohno-Iwashita, and S. Ando. 1987. Role of the essential thiol group in the thiol-activated cytolysin from Clostridium perfringens. European journal of biochemistry 167: 425-430.

102. Liu, W., and H. Li. 2020. COVID-19: attacks the 1-beta chain of hemoglobin and captures the porphyrin to inhibit human heme metabolism. ChemRxiv. Preprint. chemrxiv.11938173.v9.

103. Dewi, D. A. P., and W. T. Utama. 2021. 'Happy'Hipoksemia pada pasien COVID-19. Medical Profession Journal of Lampung 10: 677-684.

104. Daniel, Y., B. J. Hunt, A. Retter, K. Henderson, S. Wilson, C. C. Sharpe, and M. J. Shattock. 2020. Haemoglobin oxygen affinity in patients with severe COVID-19 infection. British journal of haematology 190: e126-e127.

105. Laredo, M., E. Curis, E. Masson-Fron, S. Voicu, and B. Mégarbane. 2021. Does COVID-19 alter the oxyhemoglobin dissociation curve?-An observational cohort study using a mixed-effect modelling. Clinical Chemistry and Laboratory Medicine (CCLM).

106. DeMartino, A. W., J. J. Rose, M. B. Amdahl, M. R. Dent, F. A. Shah, W. Bain, B. J. McVerry, G. D. Kitsios, J. Tejero, and M. T. Gladwin. 2020. No evidence of hemoglobin damage by SARS-CoV-2 infection. Haematologica 105: 2769-2773.

107. Gille, T., L. Sesé, E. Aubourg, E. E. Fabre, F. Cymbalista, K. C. Ratnam, D. Valeyre, H. Nunes, J.-P. Richalet, and C. Planès. 2021. The Affinity of Hemoglobin for Oxygen Is Not Altered During COVID-19. Frontiers in Physiology 12.

108. Shattock, M. J., Y. Daniel, B. J. Hunt, A. Retter, K. Henderson, S. Wilson, and C. C. Sharpe. 2020. COVID-19 and haemoglobin oxygen affinity: some clarity? British journal of haematology 190: 723-724.

109. Otero, T. M., D. D. Yeh, E. K. Bajwa, R. J. Azocar, A. L. Tsai, D. M. Belcher, and S. A. Quraishi. 2018. Elevated red cell distribution width is associated with decreased ventilator-free days in critically ill patients. Journal of intensive care medicine 33: 241-247.

110. Henry, B. M., J. L. Benoit, S. Benoit, C. Pulvino, B. A. Berger, M. H. S. d. Olivera, C. A. Crutchfield, and G. Lippi. 2020. Red Blood Cell Distribution Width (RDW) Predicts COVID-19 Severity: A Prospective, Observational Study from the Cincinnati SARS-CoV-2 Emergency Department Cohort. Diagnostics 10: 618.

111. Lippi, G., C. Mattiuzzi, and G. Cervellin. 2016. Learning more and spending less with neglected laboratory parameters: the paradigmatic case of red blood cell distribution width. Acta Biomed 87: 323-328.

112. Nóbrega, F., V. A. Q. Mauad, and D. M. M. Borducchi. 2020. Does COVID-19 really impact on the oxy-hemoglobin dissociation curve? eJHaem 1: 604-607. 
113. Karalyan, Z., L. Hakobyan, L. Abroyan, A. Avetisyan, H. Avagyan, S. Hakobyan, N. Bayramyan, H. Voskanyan, L. Niazyan, and M. Davidyants. 2021. Red Blood Cells Pathology in Patients with Coronavirus Disease 2019 (COVID-19).

114. Rubano, J. A., L. M. Maloney, J. Simon, D. N. Rutigliano, I. Botwinick, R. S. Jawa, M. J. Shapiro, J. A. Vosswinkel, M. Talamini, and K. Kaushansky. 2021. An Evolving Clinical Need: Discordant Oxygenation Measurements of Intubated COVID-19 Patients. Annals of Biomedical Engineering 49: 959-963.

115. English, M., B. Muambi, S. Mithwani, and K. Marsh. 1997. Lactic acidosis and oxygen debt in African children with severe anaemia. QJM: monthly journal of the Association of Physicians 90: 563-569.

116. Sasi, P., S. P. Burns, C. Waruiru, M. English, C. L. Hobson, C. G. King, M. Mosobo, J. S. Beech, R. A. Iles, B. J. Boucher, and R. D. Cohen. 2007. Metabolic Acidosis and Other Determinants of Hemoglobin-Oxygen Dissociation in Severe Childhood Plasmodium falciparum Malaria. The American Journal of Tropical Medicine and Hygiene Am J Trop Med Hyg 77: 256-260.

117. Alberti, K., P. Emerson, J. Darley, and T. Hockaday. 1972. 2, 3-Diphosphoglycerate and tissue oxygenation in uncontrolled diabetes mellitus. The Lancet 300: 391-395.

118. Bellingham, A., J. Detter, and C. Lenfant. 1971. Regulatory mechanisms of hemoglobin oxygen affinity in acidosis and alkalosis. J Clin Invest 50: 700-706.

119. Krishna, S., E. Shoubridge, N. White, D. Weatherall, and G. Radda. 1983. Plasmodium yoelii: blood oxygen and brain function in the infected mouse. Experimental parasitology 56: 391-396.

120. Cohen, R. 1994. Lactic acidosis: new perspectives on origins and treatment. Diabetes Reviews 2: 86-97.

121. Böning, D., W. M. Kuebler, and W. Bloch. 2021. The Oxygen Dissociation Curve of Blood in COVID-19. American Journal of Physiology-Lung Cellular and Molecular Physiology.

122. Schmidt, W., R. Correa, D. Boning, J. Ehrich, and C. Kruger. 1994. Oxygen transport properties in malaria-infected rodents--a comparison between infected and noninfected erythrocytes.

123. Dasgupta, R., R. Verma, S. Ahlawat, A. Uppal, and P. Gupta. 2011. Studies on erythrocytes in malaria infected blood sample with Raman optical tweezers. Journal of Biomedical Optics 16: 077009.

124. Sobotka, H., and C. P. Stewart. 1964. Advances in clinical chemistry. Academic Press.

125. Luzzatto, L. 2012. Sickle cell anaemia and malaria. Mediterranean journal of hematology and infectious diseases 4: e2012065.

126. Hochman, S., and K. Kim. 2009. The Impact of HIV and Malaria Coinfection: What Is Known and Suggested Venues for Further Study. Interdisciplinary perspectives on infectious diseases 2009: 617954.

127. Allen, A., C. Fisher, A. Premawardhena, T. Peto, S. Allen, M. Arambepola, V. Thayalsutha, N. Olivieri, and D. Weatherall. 2010. Adaptation to anemia in hemoglobin E- $\beta$ thalassemia. Blood 116: 5368-5370. 
Table 1. Related sequences are used to search for conserved domains

\begin{tabular}{cccc}
\hline No. & Related Protein & Keywords & Count \\
\hline 1 & Antigen & Antigen & 505,583 \\
2 & complement & complement & 66,078 \\
3 & Hemolysis & Hemolysis & 9,175 \\
4 & glycophorin & glycophorin & 1,004 \\
5 & Erythrocyte membrane protein & Erythrocyte+membrane+protein & 21,928 \\
6 & Autotransporter & Autotransporter & 98,365 \\
\hline
\end{tabular}


Table 2. Motifs of TryThrA_C domain of SARS-COV-2 virus proteins

\begin{tabular}{|c|c|c|c|c|}
\hline Protein & Alias & Motif & Start & End \\
\hline \multirow[t]{4}{*}{$\mathrm{S}$} & A & HKNNKSWMESEFRVYS & 146 & 161 \\
\hline & B & IDGYFKIYSKHTPINLVRDLPQGFSALEPLVDLPIGINITR & 197 & 237 \\
\hline & $\mathrm{C}$ & GWTFGAGAALQIPFAMQMAYRFNGIGVTQNVLY & 885 & 917 \\
\hline & $\mathrm{D}$ & $\begin{array}{l}\text { ELGKYEQYIKWPWYIWLGFIAGLIAIVMVTIMLCCMTSCCSCLK } \\
\text { GCCS }\end{array}$ & 1202 & 1249 \\
\hline $\mathrm{E}$ & A & TLAILTALRLCAYCCNIVNVSLVKPSFYVYSRVKNLNSSRVP & 30 & 71 \\
\hline \multirow[t]{5}{*}{ M } & A & QWNLVIGFLFLTWICLLQFAYANRNRFLYIIKLIFLW & 19 & 55 \\
\hline & B & WPVTLACFVLAAVYRINWITGGIAIAMACLVGLMWLSYFIASF & 58 & 114 \\
\hline & & RLFARTRSMWSFNP & & \\
\hline & $\mathrm{C}$ & ILRGHLRIAGHHLGRCDIKDL & 144 & 164 \\
\hline & $\mathrm{D}$ & SQRVAGDSGFAAYSRYRIGNYKLNTDHSSSSDNIALLVQ & 184 & 222 \\
\hline \multirow[t]{3}{*}{$\mathrm{N}$} & A & $\begin{array}{l}\text { QGVPINTNSSPDDQIGYYRRATRRIRGGDGKMKDLSPRWYFYY } \\
\text { L }\end{array}$ & 70 & 113 \\
\hline & B & HWPQIAQFAPSASAFFGMSRIGMEVTPSGTWLTY & 300 & 333 \\
\hline & $\mathrm{C}$ & IKLDDKDPNFKDQVILLNKHIDAYKTF & 337 & 363 \\
\hline \multirow[t]{2}{*}{ ORF3a } & A & $\begin{array}{l}\text { LAVFQSASKIITLKKRWQLALSKGVHFVCNLLLLFVTVYSHLLL } \\
\text { VAAGLEAPFLYLYALVYFLQSINFVRIIMRLWLCWKCRSKNPLL } \\
\text { YDANYFLCWHTNCYDYCIPYNSV }\end{array}$ & 53 & 163 \\
\hline & B & SYFTSDYYQLYSTQLSTDTGVEHVTFFIYNKI & 205 & 236 \\
\hline ORF6 & A & MFHLVDFQVTIAEILLIIMRTFKVSIWNLDYIINLIIKNLSKS & 1 & 43 \\
\hline ORF7a & A & $\begin{array}{l}\text { LFLALITLATCELYHYQECVRGTTVLLKEPCSSGTYEGNSPFHPL } \\
\text { ADNKFALTCFSTQFAFACPDGVKHVYQLRARSVSPKLFIRQEEV } \\
\text { QELYSPIFLIVAAIVFITLCF }\end{array}$ & 5 & 114 \\
\hline ORF7b & A & MIELSLIDFYLCFLAFLLFLVLIMLIIFWFSLELQDHNETCHA & 1 & 43 \\
\hline ORF8 & A & $\begin{array}{l}\text { MKFLVFLGIITTVAAFHQECSLQSCTQHQPYVVDDPCPIHFYSK } \\
\text { WYIRVGARKSAPLIELCVDEAGSKSPIQYIDIGNYTVSCLPFTIN } \\
\text { CQEPKLGSLVVRCSFYEDFLEYHDVRV }\end{array}$ & 1 & 116 \\
\hline ORF10 & A & MGYINVFAFPFTIYSLLLCRMNSRNYIAQVDVVNFNLT & 1 & 38 \\
\hline \multirow[t]{2}{*}{ nsp2 } & A & EQLDFIDTKRGVYCCREHEHEIAWYTERSEK & 37 & 67 \\
\hline & B & IQPRVEKKKLDGFMGRIRSVY & 104 & 124 \\
\hline nsp3 & A & $\begin{array}{l}\text { YFAVHFISNSWLMWLIINLVQMAPISAMVRMYIFFASFYYVWK } \\
\text { SYVHVVDGCNSSTCMMC }\end{array}$ & 1535 & 1594 \\
\hline nsp4 & A & AHIQWMVMFTPLVPFWITIAYIICISTKHFYWFFSN & 361 & 396 \\
\hline \multirow[t]{3}{*}{ RdRP } & A & YWDQTYHPNCVNCLDDRCILHC & 289 & 310 \\
\hline & B & $\begin{array}{l}\text { KFYGGWHNMLKTVYSDVENPHLMGWDYPKCDRAMPNMLRI } \\
\text { M }\end{array}$ & 593 & 633 \\
\hline & $\mathrm{C}$ & YLQYIRKLHDELTGHMLDMY & 884 & 903 \\
\hline helicase & A & SAQCFKMFYKGVITHDVSSAINRPQIGVVREFLTRNPAWR & 468 & 507 \\
\hline $\begin{array}{l}3^{\prime} \text {-to-5' } \\
\text { exonucl }\end{array}$ & A & $\begin{array}{l}\text { YRRLISMMGFKMNYQVNGYPNMFITREEAIRHVRAWIGFDVE } \\
\text { GCHATR }\end{array}$ & 51 & 98 \\
\hline ease & B & $\begin{array}{l}\text { DTYACWHHSIGFDYVYNPFMIDVQQWGFTGNLQSNHDLYCQV } \\
\text { HG }\end{array}$ & 222 & 265 \\
\hline
\end{tabular}




\begin{tabular}{cllll}
$\begin{array}{c}\text { 2'-O-rib } \\
\text { ose }\end{array}$ & WWTAFVTNVNASSSEAFLIGCNYLGKPREQIDGYVMHANYIF & 189 & 238 \\
methylt & WRNTNPIQ \\
ransfera & \\
se & & & \\
\hline
\end{tabular}


Table 3. Motifs of the EBA-175 VI domain of SARS-COV-2 virus proteins

\begin{tabular}{cclcc}
\hline Protein & Alias & \multicolumn{1}{c}{ Motif } & Start & End \\
\hline E & A & YCCNIVNVSLVKPSFYVYSR & 42 & 61 \\
M & A & WPVTLACFVLAAVYRINWITGGIAIAMACLVGLMWLSYFIA & 58 & 98 \\
N & A & TDYKHWPQI & 296 & 304 \\
ORF3a & A & IIMRLWLCWKCRSKNPLLYDANYFLCW & 123 & 149 \\
ORF6 & A & MFHLVDFQVTIAEILLIIMRTFKVSIWNL & 1 & 29 \\
ORF7a & A & YHYQECV & 18 & 24 \\
& B & FHPLADNKFALTCFSTQFAFACPDGVKHVYQLRA & 46 & 79 \\
ORF7b & A & FYLCFLAFLLFLVLIMLIIFWFSLELQDHNETC & 9 & 41 \\
ORF8 & A & FLVFLGIITTVAAFHQECSLQSCTQHQPYVVDDPCPIHFYSKWYIR & 3 & 61 \\
& & VGARKSAPLIELC & & \\
ORF10 & A & INVFAFPFTIYSLLLCRMNSRNYIAQV & 4 & 30 \\
\hline
\end{tabular}


Table 4. Motifs of the C1q domain of SARS-COV-2 virus proteins

\begin{tabular}{|c|c|c|c|c|}
\hline Protein & Alias & Motif & Start & End \\
\hline \multirow[t]{4}{*}{$\mathrm{S}$} & A & VYYHKNNKSWMESEFR & 143 & 158 \\
\hline & B & AMQMAYR & 899 & 905 \\
\hline & $\mathrm{C}$ & YIKWPWYIW & 1209 & 1217 \\
\hline & $\mathrm{D}$ & TIMLCCMTSCCSCLKGCCSCGSCCKFDEDDSEP & 1231 & 1263 \\
\hline \multirow[t]{2}{*}{$\mathrm{E}$} & A & MYSFVSEETGTLIVNSVLLFLAFVVFLLVTLAILTALRLCAYCCN & 1 & 72 \\
\hline & & IVNVSLVKPSFYVYSRVKNLNSSRVPD & & \\
\hline \multirow[t]{5}{*}{ M } & A & MADSNGTITVEELKKLLEQWN & 1 & 21 \\
\hline & B & TWICLLQFAYANRNRF & 30 & 45 \\
\hline & $\mathrm{C}$ & KLIFLWLLWPVTLACFVLAAVYRINWITGGIAIAMACLVGLMW & 50 & 100 \\
\hline & & LSYFIASF & & \\
\hline & $\mathrm{D}$ & HHLGRCDIKDLPK & 154 & 166 \\
\hline \multirow[t]{3}{*}{$\mathrm{N}$} & A & KMKDLSPRWYFYYLGTGPEAGLPYGANKDGIIWVATE & 100 & 136 \\
\hline & B & IRQGTDYKHWPQIAQFAPSASAFFGMSRIGMEVT & 292 & 325 \\
\hline & $\mathrm{C}$ & YTGAIKLDDKDPNFKDQVILLNKHIDAYKTFPPTEP & 333 & 368 \\
\hline \multirow[t]{3}{*}{ ORF3a } & A & YFLQSINFVRIIMRLWLCWKCRSKNPLLYDANYFLCWHTNCYD & 113 & 171 \\
\hline & & YCIPYNSVTSSIVITS & & \\
\hline & B & YQIGGYTEKWESGVKDCVVL & 184 & 203 \\
\hline \multirow[t]{2}{*}{ ORF6 } & A & MFHLVDFQVTIAEILLIIMRTFKVSIWNLDYIINLIIKNLSKSLTEN & 1 & 61 \\
\hline & & KYSQLDEEQPMEID & & \\
\hline \multirow[t]{3}{*}{ ORF7a } & A & MKIILFLALITLATCELYHYQECVRGTTVLLKEPC & 1 & 35 \\
\hline & B & YEGNSPFHPLADNKFALTCFSTQFAFACPDGVKHVYQLRARSV & 40 & 97 \\
\hline & & SPKLFIRQEEVQELY & & \\
\hline ORF7b & A & MIELSLIDFYLCFLAFLLFLVLIMLIIFWFSLELQDHNETCHA & 1 & 43 \\
\hline \multirow[t]{3}{*}{ ORF8 } & A & VFLGIITTVAAFHQECSLQSCTQHQPYVVDDPCPIHFYSKWYIR & 5 & 117 \\
\hline & & VGARKSAPLIELCVDEAGSKSPIQYIDIGNYTVSCLPFTINCQEPK & & \\
\hline & & LGSLVVRCSFYEDFLEYHDVRVV & & \\
\hline ORF10 & A & MGYINVFAFPFTIYSLLLCRMNSRNYIAQVDVVNFNLT & 1 & 38 \\
\hline nsp2 & A & CREHEHEIAWYTER & 51 & 64 \\
\hline nsp4 & A & AHIQWMVMFTPLVP & 361 & 374 \\
\hline 3C-like & A & YMHHME & 161 & 166 \\
\hline
\end{tabular}


Table 5. Motifs of MACPF domain of SARS-COV-2 virus proteins

\begin{tabular}{cclcc}
\hline Protein & Alias & \multicolumn{1}{c}{ Motif } & Start & End \\
\hline S & A & LQELGKYEQYIKWPWYIWL & 1200 & 1218 \\
E & A & PSFYVYSRVKNLNSSRVPDLL & 54 & 74 \\
M & A & GASQRVAGDSGFAAYSRYRIGNYKLNTDHSSSSDNIALLVQ & 182 & 222 \\
N & A & TDYKHWPQ & 296 & 303 \\
ORF3a & A & FMRIFT & 4 & 9 \\
& B & YFLQSINFVRIIMRLWLCWKCRSKNPLLYDANYFLCWHTNCYD & 113 & 159 \\
& & YCIP & 1 & 60 \\
ORF6 & A & MFHLVDFQVTIAEILLIIMRTFKVSIWNLDYIINLIIKNLSKSLTEN & 1 & \\
& & KYSQLDEEQPMEI & 17 & 66 \\
ORF7a & A & LYHYQECVRGTTVLLKEPCSSGTYEGNSPFHPLADNKFALTCFS & 17 \\
ORF7b & A & MIELSLIDFYLCFLAFLLFLVLIMLIIFWFSLELQDHNETCHA & 1 & 43 \\
ORF8 & A & QECSLQSCTQHQPYVVDDPCPIHFYSKWYIRVGARKSAP & 18 & 56 \\
ORF10 & A & MGYINVFAFPFTIYSLLLCRMNSRNYIAQ & 1 & 29 \\
nsp2 & A & CREHEHEIAWYTERSEKSYELQ & 51 & 72 \\
nsp4 & A & PFWITIAYIICISTKHFYWFFSN & 374 & 396 \\
nsp10 & A & CRCHIDHPN & 77 & 85 \\
3C-like & A & SFCYMHHME \\
exonuclease & A & CCLCDRRATCFSTASDTYACWHHSIGF & 158 & 166 \\
\hline
\end{tabular}


Table 6. MACPF auxiliary domains of SARS-COV-2 virus proteins

\begin{tabular}{|c|c|c|c|c|}
\hline Protein & Domain & Motif & Start & End \\
\hline \multirow[t]{5}{*}{$\mathrm{S}$} & TSP type-1 & KWPWYIW & 1211 & 1217 \\
\hline & EGF-like & CCMTSCCSCLKGC & 1235 & 1247 \\
\hline & $\mathrm{C} 2$ & WMESEFRVY & 152 & 160 \\
\hline & & IDRLITGRLQSLQTYVTQQLIRAAEIRASANLAATKMSECV & 993 & 1033 \\
\hline & & KWPWYIWLG & 1211 & 1219 \\
\hline M & $\mathrm{C} 2$ & $\begin{array}{l}\text { WITGGIAIAMACLVGLMWLSYFIASFRLFARTRSMWSFNP } \\
\text { ETNI }\end{array}$ & 75 & 118 \\
\hline \multirow[t]{2}{*}{$\mathrm{N}$} & $\mathrm{C} 2$ & $\begin{array}{l}\text { ARSKQRRPQGLPNNTASWFTALTQHGKEDLKFPRGQGVP } \\
\text { INTNSSPDD }\end{array}$ & 35 & 82 \\
\hline & & TDYKHW & 296 & 301 \\
\hline \multirow[t]{2}{*}{ ORF3a } & EGF-like & CWHTNCYDYC & 148 & 157 \\
\hline & $\mathrm{C} 2$ & $\begin{array}{l}\text { NFVRIIMRLWLCWKCRSKNPLLYDANYFLCWHTNCYDY } \\
\text { CIPY }\end{array}$ & 119 & 160 \\
\hline \multirow[t]{2}{*}{ ORF6 } & EGF-like & $\begin{array}{l}\text { MFHLVDFQVTIAEILLIIMRTFKVSIWNLDYIINLIIKNLSKS } \\
\text { LTENKY }\end{array}$ & 1 & 49 \\
\hline & $\mathrm{C} 2$ & MFHLVDFQVTIAEILLIIMRTFKVSIWNLDYIINLII & 1 & 37 \\
\hline ORF7a & $\mathrm{C} 2$ & LIVAAIVFITLCFTLKRKTE & 102 & 121 \\
\hline \multirow[t]{3}{*}{ ORF7b } & EGF-like & QDHNETCH & 35 & 42 \\
\hline & FIMAC & QDHNET & 35 & 40 \\
\hline & $\mathrm{C} 2$ & IELSLIDFYLCFLAFLLFLVLIMLIIFWFSLELQDHNETCHA & 2 & 43 \\
\hline \multirow[t]{3}{*}{ ORF8 } & TSP type-1 & QHQPYVVDDPCPIHFYSKW & 27 & 45 \\
\hline & EGF-like & QHQPYVVDDPCPIHFYSKWYIRVGARKSAPLIELCVDEA & 27 & 65 \\
\hline & $\mathrm{C} 2$ & HQECSLQSCTQHQPYVVDDPCPIHFYSKWYIR & 17 & 48 \\
\hline \multirow[t]{2}{*}{ ORF10 } & EGF-like & LCRMNSRNYI & 18 & 27 \\
\hline & $\mathrm{C} 2$ & MGYINVFAFPFTIYSLLLCRMNSRNYIAQVDVVNFN & 1 & 36 \\
\hline nsp4 & $\mathrm{C} 2$ & HIQWMVM & 362 & 368 \\
\hline
\end{tabular}


Table 7. The motifs of the Thiol-activated cytolysin domain of SARS-COV-2 virus proteins

\begin{tabular}{|c|c|c|c|}
\hline Protein & Motif & Start & End \\
\hline $\mathrm{S}$ & WPWYIW & 1212 & 1217 \\
\hline $\mathrm{E}$ & LTALRLCAYCCNI & 34 & 46 \\
\hline $\mathrm{N}$ & YYRRATRRIRGGDGKMKDLSPRWYFYY & 86 & 112 \\
\hline ORF3a & RIIMRLWLCWKCRSKNPLLYDANYFLCWHTNCYDYCIPY & 122 & 160 \\
\hline ORF6 & YSQLDEEQPM & 49 & 58 \\
\hline ORF7a & QECVRG & 21 & 26 \\
\hline ORF7b & DFYLCFLAFLLFLVLIMLIIFWFSLELQDHNETCH & 8 & 42 \\
\hline \multirow[t]{2}{*}{ ORF8 } & AAFHQECSLQSCTQHQPYVVDDPCPIHFYSKWYIRVGARKSAPLIELCVD & 14 & 70 \\
\hline & EAGSKSP & & \\
\hline ORF10 & MKFLVFLGIITTVAA & 1 & 15 \\
\hline nsp3 & WLMWLIINLVQMAP & 1545 & 1558 \\
\hline
\end{tabular}


Table 8 . The $4.1 \mathrm{~m}$ domain of SARS-COV-2 virus proteins

\begin{tabular}{cclcc}
\hline Protein & Alias & \multicolumn{1}{c}{ Motif } & Start & End \\
\hline S & A & YYHKNNKSWMESE & 144 & 156 \\
& B & RVDFCGKGYHLM & 1039 & 1050 \\
& C & YEQYIKWPWYIW & 1206 & 1217 \\
& D & IVMVTIMLCCMTSCC & 1227 & 1241 \\
N & A & MKDLSPRWYFYYL & 101 & 113 \\
& B & NFGDQELIRQGTDYKHWP & 285 & 302 \\
& C & FFGMSRIGMEVTPSGTWLTY & 314 & 333 \\
ORF3a & A & MRLWLCWKCRSKN & 125 & 137 \\
ORF7a & A & HYQECVRG & 19 & 26 \\
ORF7b & A & MLIIFWFSLELQDHNETCH & 24 & 42 \\
RdRP & A & RYFKYWDQTYHPNC & 285 & 298 \\
\hline & & & &
\end{tabular}


Table 9. Band_3_cyto domain of SARS-COV-2 virus proteins

\begin{tabular}{clcc}
\hline Protein & \multicolumn{1}{c}{ Motif } & Start & End \\
\hline E & CAYCCN & 40 & 45 \\
ORF3a & YDANYFLCWHTNCYDY & 141 & 156 \\
ORF7a & TCELYHYQECVR & 14 & 25 \\
ORF7b & QDHNETCHA & 35 & 43 \\
ORF8 & FHQECSLQSCTQHQPYVVDDPCPIHFYSKWYIRVGAR & 16 & 52
\end{tabular}


Table 10. Autotransporter domain of SARS-COV-2 virus proteins

\begin{tabular}{|c|c|c|c|c|}
\hline Domain & Alias & Motif & Start & End \\
\hline \multirow[t]{19}{*}{$\mathrm{s}$} & A & MFVFLVLLPLVSSQCVNLTTRTQLPPAYTNSFTRGVYYPDKVFRSSVLHSTQDLFLPFFSNVTWFHAI & 1 & 82 \\
\hline & & HVSGTNGTKRFDNP & & \\
\hline & B & LIVNNATNVVIKVCEFQFCNDPFLGVYYHKNNKSWMESEFRVYSSANNCTFEYVSQPFLMDLEGKQ & 118 & 237 \\
\hline & & GNFKNLREFVFKNIDGYFKIYSKHTPINLVRDLPQGFSALEPLVDLPIGINITR & & \\
\hline & $\mathrm{C}$ & PRTFLLKYNENGTITDAVDCALDPLSETKCTLKSFTVEKGIYQTSNFRVQPTESIVRFPNITNLCPFGEV & 272 & 379 \\
\hline & & FNATRFASVYAWNRKRISNCVADYSVLYNSASFSTFKC & & \\
\hline & D & KLPDDFTGCVIAWNSNNLDSKVGGNYNYLYRLFRKSNLKPFERDISTEIYQAGSTPCNGVEGFNCYF & 424 & 538 \\
\hline & & PLQSYGFQPTNGVGYQPYRVVVLSFELLHAPATVCGPKKSTNLVKNKC & & \\
\hline & E & YQDVNCTEVPVAIHADQLTPTWRVY & 612 & 636 \\
\hline & $\mathrm{F}$ & FQTRAGCLIGAEHVNNSYECDIPIGAGICASYQTQTNSPRRARSVASQSIIAYTMS & 643 & 698 \\
\hline & G & EILPVSMTKTSVDCTMYICGDSTECSNLLLQYGSFCTQLNRALTGIAVEQDKNTQEVFAQVKQIYKTP & 725 & 847 \\
\hline & & PIKDFGGFNFSQILPDPSKPSKRSFIEDLLFNKVTLADAGFIKQYGDCLGDIAAR & & \\
\hline & $\mathrm{H}$ & LQIPFAMQMAYRFNGIGVTQNVLYENQKLIANQFNSAIGKIQD & 894 & 936 \\
\hline & I & RLDKVEAEVQIDRLITGRLQSLQTYVTQQLIRAAEIRASANLAATKMSECVLGQSKRVDFCGKGYHL & 983 & 1128 \\
\hline & & MSFPQSAPHGVVFLHVTYVPAQEKNFTTAPAICHDGKAHFPREGVFVSNGTHWFVTQRNFYEPQIIT & & \\
\hline & & TDNTFVSGNCDV & & \\
\hline & $\mathrm{J}$ & IVNNTVYDPLQPELDSFKEELDKYFKNHTSPDVDLGDISGINASVVNIQKEIDRLNEVAKNLNESLIDL & 1132 & 1272 \\
\hline & & QELGKYEQYIKWPWYIWLGFIAGLIAIVMVTIMLCCMTSCCSCLKGCCSCGSCCKFDEDDSEPVLKG & & \\
\hline & & VKLHY & & \\
\hline \multirow[t]{7}{*}{$\mathrm{N}$} & A & QRNAPRITFGGPSDSTGSNQNGERSGARSKQRRPQGLPNNTASWFTALTQHGKEDLKFPRGQGVPIN & 9 & 171 \\
\hline & & TNSSPDDQIGYYRRATRRIRGGDGKMKDLSPRWYFYYLGTGPEAGLPYGANKDGIIWVATEGALNT & & \\
\hline & & PKDHIGTRNPANNAAIVLQLPQGTTLPKGF & & \\
\hline & B & SPARMAGNGGDAALALLLLDRLNQLESKMSGKGQQQQGQTVTKKSAAEASKKPRQKRTATKAYN & 206 & 418 \\
\hline & & VTQAFGRRGPEQTQGNFGDQELIRQGTDYKHWPQIAQFAPSASAFFGMSRIGMEVTPSGTWLTYTG & & \\
\hline & & AIKLDDKDPNFKDQVILLNKHIDAYKTFPPTEPKKDKKKKADETQALPQRQKKQQTVTLLPAADLD & & \\
\hline & & DFSKQLQQSMSSADSTQ & & \\
\hline \multirow[t]{4}{*}{ M } & A & MADSNGTITVEELKKLLEQWNLVIGFLFLTWICLLQFAYANRNRFLYIIKLIFLWLLWPVTLACFVLA & 1 & 222 \\
\hline & & AVYRINWITGGIAIAMACLVGLMWLSYFIASFRLFARTRSMWSFNPETNILLNVPLHGTILTRPLLESE & & \\
\hline & & LVIGAVILRGHLRIAGHHLGRCDIKDLPKEITVATSRTLSYYKLGASQRVAGDSGFAAYSRYRIGNYK & & \\
\hline & & LNTDHSSSSDNIALLVQ & & \\
\hline \multirow[t]{2}{*}{ E } & A & MYSFVSEETGTLIVNSVLLFLAFVVFLLVTLAILTALRLCAYCCNIVNVSLVKPSFYVYSRVKNLNSSR & 1 & 75 \\
\hline & & VPDLLV & & \\
\hline \multirow[t]{5}{*}{ ORF3a } & A & MDLFMRIFTIGTVTLKQGEIKDATPSDFVRATATIPIQASLPFGWLIVGVALLAVFQSASKIITLKKRW & 1 & 275 \\
\hline & & QLALSKGVHFVCNLLLLFVTVYSHLLLVAAGLEAPFLYLYALVYFLQSINFVRIIMRLWLCWKCRSK & & \\
\hline & & NPLLYDANYFLCWHTNCYDYCIPYNSVTSSIVITSGDGTTSPISEHDYQIGGYTEKWESGVKDCVVLH & & \\
\hline & & SYFTSDYYQLYSTQLSTDTGVEHVTFFIYNKIVDEPEEHVQIHTIDGSSGVVNPVMEPIYDEPTTTTSV & & \\
\hline & & PL & & \\
\hline ORF6 & A & MFHLVDFQVTIAEILLIIMRTFKVSIWNLDYIINLIIKNLSKSLTENKYSQLDEEQPMEID & 1 & 61 \\
\hline \multirow[t]{2}{*}{ ORF7a } & A & MKIILFLALITLATCELYHYQECVRGTTVLLKEPCSSGTYEGNSPFHPLADNKFALTCFSTQFAFACPD & 1 & 121 \\
\hline & & GVKHVYQLRARSVSPKLFIRQEEVQELYSPIFLIVAAIVFITLCFTLKRKTE & & \\
\hline ORF7b & A & MIELSLIDFYLCFLAFLLFLVLIMLIIFWFSLELQDHNETCHA & 1 & 43 \\
\hline ORF8 & A & MKFLVFLGIITTVAAFHQECSLQSCTQHQPYVVDDPCPIHFYSKWYIRVGARKSAPLIELCVDEAGSK & 1 & 121 \\
\hline
\end{tabular}


SPIQYIDIGNYTVSCLPFTINCQEPKLGSLVVRCSFYEDFLEYHDVRVVLDFI

\begin{tabular}{|c|c|c|c|c|}
\hline ORF10 & A & MGYINVFAFPFTIYSLLLCRMNSRNYIAQVDVVNFNLT & 1 & 38 \\
\hline \multirow[t]{3}{*}{ nsp2 } & A & LDFIDTKRGVYCCREHEHEIAWYTER & 39 & 64 \\
\hline & B & ECNQMCLSTLMKCDHCGETSW & 131 & 151 \\
\hline & $\mathrm{C}$ & CHNKCAYWVPRAS & 236 & 248 \\
\hline \multirow[t]{3}{*}{ nsp3 } & A & EEEGDCEEEEFEPSTQYEYGTEDDYQGKPLE & 113 & 143 \\
\hline & B & WLIINLVQMAPISAMVRMYIFFASFYYVW & 1548 & 1576 \\
\hline & $\mathrm{C}$ & HNWNCVNC & 1630 & 1637 \\
\hline nsp4 & A & HIQWMVMFTP & 362 & 371 \\
\hline nsp6 & A & YFNMVYMPASWVMRIMTWLDM & 80 & 100 \\
\hline \multirow[t]{3}{*}{ RdRP } & A & DMVPHISRQRLTKYTM & 109 & 124 \\
\hline & B & WHNMLKTVYSDVENPHLMGWDYPKCDRAMPNMLRIM & 598 & 633 \\
\hline & $\mathrm{C}$ & EFYAYLRKHFSMMI & 744 & 757 \\
\hline 3'-to-5' & A & RHVRAW & 81 & 86 \\
\hline \multirow[t]{2}{*}{ exonuclease } & B & DRRATCFSTASDTYACWHHSIGFDYVYNPFMIDVQQWGFTGNLQSNHDLYCQVHGNAH & 211 & 268 \\
\hline & $\mathrm{C}$ & ATHSDKFTDGVCLFWNCNVDRYP & 371 & 393 \\
\hline endoRNAse & A & PRSQMEI & 205 & 211 \\
\hline 2'-O-ribose & A & EHSWNADLYKLMGHFAWWT & 173 & 191 \\
\hline methyltransf & B & YVMHANYIFWRNTNPIQLSSYS & 222 & 243 \\
\hline
\end{tabular}




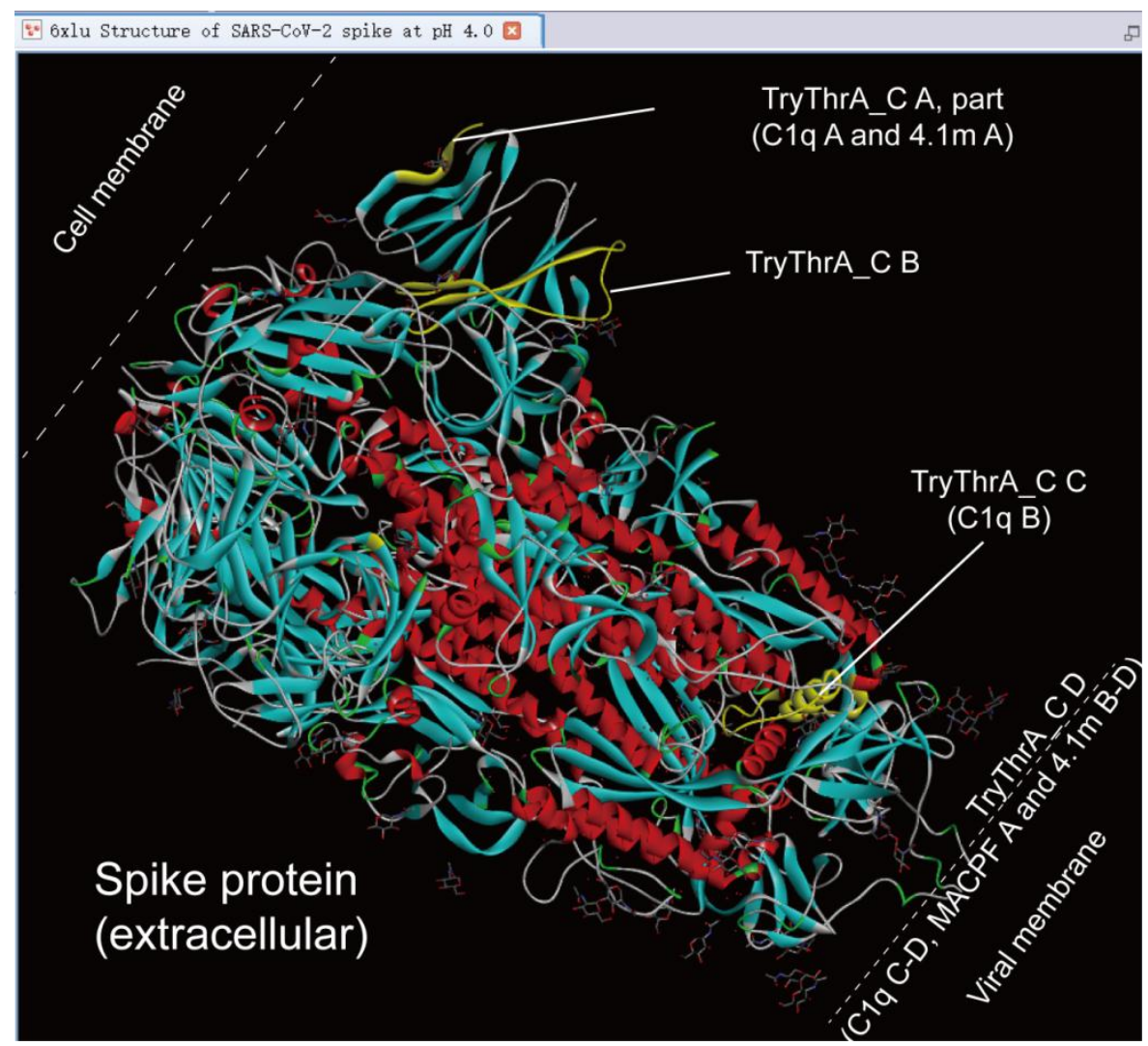

Figure 1. Schematic diagram of the TryThrA_C, C1q, MACPF, and $4.1 \mathrm{~m}$ domains of SARS-COV-2 S protein (PDBID: 6xlu). 6xlu is a trimer and has only the extracellular region of the virus. TryThrA_C A-C is in the extracellular region of the virus. TryThrA_C D is across the viral membrane and intracellular. It only marks the domain of one monomer, and the domains of other monomers are the same. 
A

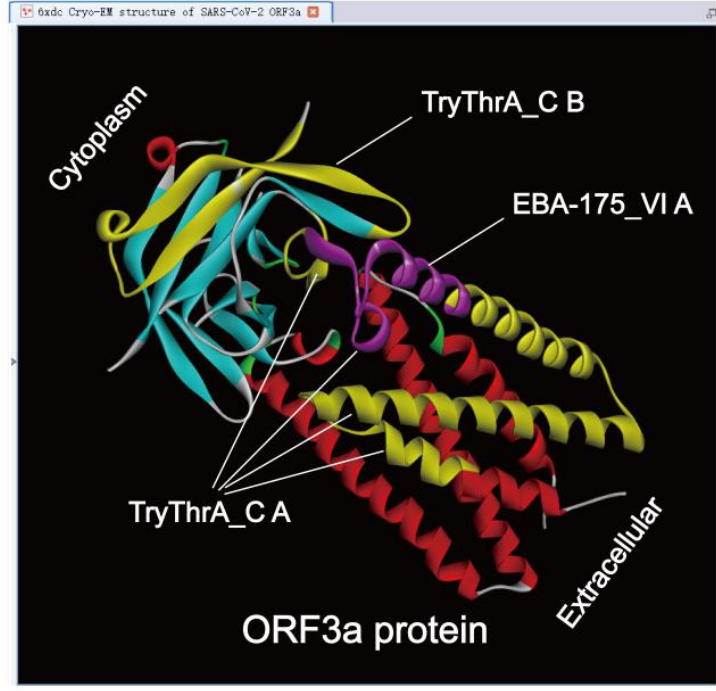

$B$

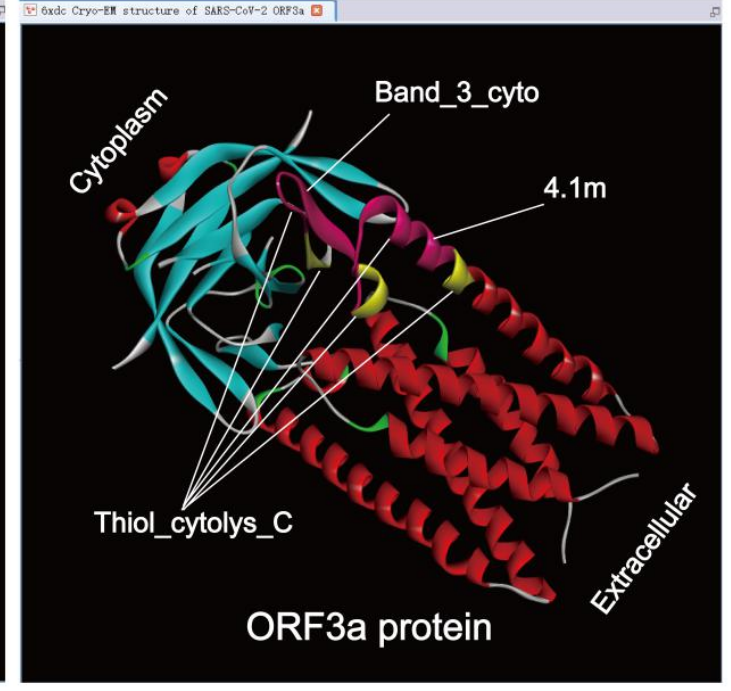

Figure 2. Schematic diagram of the binding region of the Plasmodium antigen and erythrocyte membrane protein (ORF3a protein, PDBID: 6xdc). A. Plasmodium antigen distribution area of ORF3a protein. B. The distribution area where the hemolysin of ORF3a protein binds to the red blood cell membrane protein. It only marks the domain of one monomer, and the domains of other monomers are the same. 